Research Article

\title{
Forest Loss and Susceptible Area Prediction at Sefwi Wiawso District (SWD), Ghana
}

\author{
William Osei-Wusu $\mathbb{D}^{1},{ }^{1}$ Jonathan Quaye-Ballard $\left(\mathbb{D},{ }^{2}\right.$ Terah Antwi $\left(\mathbb{D},{ }^{2}\right.$ \\ Naa Lamkai Quaye-Ballard (iD, ${ }^{3}$ and Alfred Awotwi $\mathbb{1}^{4}$ \\ ${ }^{1}$ Resource Management Support Center (RMSC), Forestry Commission, P.O. Box 1457, Adum, Kumasi, Ghana \\ ${ }^{2}$ Department of Geomatic Engineering, Kwame Nkrumah University of Science \& Technology (KNUST), PMB KNUST, \\ Kumasi, Ghana \\ ${ }^{3}$ Department of Geoinformatics, Building Road and Research Institute, P.O. Box 40, Kumasi, Ghana \\ ${ }^{4}$ Department of Geoinformatics and Spatial Development, University for Development Studies (UDS), P.O Box TL 1350, \\ Tamale, Ghana
}

Correspondence should be addressed to William Osei-Wusu; williamkay88@gmail.com

Received 22 April 2020; Revised 24 September 2020; Accepted 14 October 2020; Published 28 October 2020

Academic Editor: Thomas Campagnaro

Copyright (c) 2020 William Osei-Wusu et al. This is an open access article distributed under the Creative Commons Attribution License, which permits unrestricted use, distribution, and reproduction in any medium, provided the original work is properly cited.

Forests provide immeasurable merits for the economies of most developing countries. Forests in developing countries experience harmful human-induced impacts such as unregulated removal of biodiversity and unsustainable land conversion. The Sefwi Wiawso District (SWD) located in Ghana, which includes portions of six protected forest reserves (FRs) such as Muro, Tano Suhien, Tano Suraw, Suhuma, Sui River, and Krokosua, is the subject of this study. The impacts of selected spatial variables on forest losses were examined using retrospective and predictive approaches. Past deforestation patterns were analyzed using classified Landsat 5 and 7 imagery from 1984 to 2017. Pixel areas in hectares (ha) from land use land cover (LULC) classifications were used to detect land cover classes that were vulnerable to potential loss. The study also carried out a simple forest prediction using the simple moving averages (SMA) forecasting model based on the past and present deforestation patterns from LULC classification. The results showed that 3587.49 hectares (ha) of protected forest cover was converted into agricultural lands and barelands. In addition, 2532.96 hectares (ha) was converted from close forest to nonforest land cover from 2000 to 2017 , which is equivalent to a $16 \%$ reduction in close forest cover within the FRs in the SWD. This loss was also $11 \%$ higher than close forest areas between 2000 and 2010. SMA forecasting showed that from 2017 to 2024, 877.38 hectares (ha) of close forest resources will convert to open forest resources and other nonforest land cover. Subtle accessibility routes such as navigable rivers and unofficial roads are the key instigators of protected forest clearance in the Sefwi Wiawso Forest District (SWFD). The SWFD is surrounded by many communities and is susceptible to uncontrollable biodiversity removal due to lack of proper monitoring of agricultural practices, mining operations, fuelwood collection, and illegal hunting, which represents a means of livelihood for the forest fringe community dwellers. The research serves as a benchmark for similar studies in efforts to investigate, measure, and project land cover change in protected forest areas.

\section{Introduction}

The mechanics involved in understanding the depletion of forests have always been problematic. In measuring the rate of forest loss, past research studies have relied on indicators such as location, forest type, climate conditions, rainfall patterns, proximate forest dependencies, infrastructural development, population growth, and livelihoods [1, 2]. Industrial wood, fiber, food, medicines, and firewood are few benefits fringe communities derived from the protected forest. However, unsustainable forest removal for short term communal gains has resulted in adverse effects such as biodiversity loss, unpredictable climate conditions, and destruction of terrestrial biodiversity ecosystems $[3,4]$. 
Instigators of forest loss are events, structures, or practices which directly or indirectly cause the conversion of forest land cover types to nonforest land cover types [5]. The identification of direct and underlying instigators of forest loss is essential for developing plans and schemes required for sustainable forest resource management $[6,7]$. Analyzing the causes and dynamics of deforestation leads to better results at the local and rural levels, since the data collected are small in scale and thus indicate the root causes [8]. International conservation organizations have committed at least $\$ 3.4$ billion to help mitigate deforestation in Africa since 2000 , but the effects of these attempts are not readily evident due to short term objectives and goals [9].

Ghana is one of the several developing countries encouraged to reduce forest losses for reducing emissions from deforestation and forest degradation, conservation, and enhancement of carbon stocks (REDD+) benefits [10]. The development of national strategies and action plans for REDD+ in 46 developing countries has shown that commercial and subsistence agriculture is the main instigator of forest loss, whilst unsustainable logging is identified as another major degradation enhancer [11]. Human-induced factors such as fuelwood processing, charcoal production, wildfires, and livestock grazing have been identified as secondary instigators of forest removal in developing countries [11]. Despite forest management interventions by the Forestry Commission (FC) of Ghana, there is a persistent decline in protected forest infrastructure within the SWFD. Continuous removal of forest biodiversity without sufficient replacement has led to effects such as desertification, floods, deforestation, disease prevalence, and pest infestations [12]. High forests covered $79,511 \mathrm{~km}^{2}$ of land area in Ghana in 2000 but stood at $7,951.12 \mathrm{~km}^{2}$ in 2016 [13].

The development of the geographic information system (GIS) and remote sensing (RS) techniques has proved to be important in addressing challenges encountered when quantifying and identifying forest loss instigators [14-18]. Sustainable conservation methods use GIS/RS techniques to try and remain ahead of the issue $[14,15,19]$. Remote sensing analysis of time-series satellite imagery has helped to classify current and past forest cover patterns and further identified trends of forest conversion from which future forecasts can be made [20-22]. It is also easier to control forest biodiversity when ground forest data are regularly collected in the GIS environment [17, 23]. The advent of unmanned aerial vehicles (UAVs) enabled the timely retrieval and study of forest spatial data without too much exertion $[17,23]$. The International Union for Conservation of Nature ranks protected areas within SWD as category 1a where limitations on accessibility are placed on proximate dwellers, and forests are reserved for sustainable management, scientific, and biological research. However, the FRs within the SWD do not reflect these strict protective guidelines. It is based on this that the study investigates, quantifies, and forecasts forest land cover change for protected forest biodiversity in SWD using accessible roads, agriculture, and community density as spatial indicators. The study first specifically analyses the risk levels of protected forest areas based on proximity of access roads within the SWFD. The study goes on to assess the impacts of agricultural expansion and community location density on protected forest land cover conversions in SWFD. The study then predicts forest loss dynamics in the near future based on the aforementioned drivers.

\section{Materials and Methods}

The study used several time-series satellite imagery, road, and community shapefiles within the SWD to reveal conversions from forest cover to other land cover based on selected drivers within the FRs [16]. Forest cover images were classified into close forest, open forest, farmland, grassland, and bare land cover categories using the Gaussian maximum likelihood algorithm. Accuracy assessment was carried out to examine the accuracy of the classifier's prediction. Road and community shapefile data were processed using the ArcGIS toolbox to define road buffer distances and community location intensity. Resulting road and community datasets were integrated with results from LULC classification to reveal forest changes and land cover conversions in hectares (ha) within the SWD based on the drivers identified.

2.1. Study Area. The SWD (Figure 1) which has an area of 101,060 hectares (ha) is located in the Western North region of Ghana and contains the portions (Table 1) of the forest reserves (FRs) used for the study. It is bounded by Asunafo South, Atwima Mponua, Sefwi Bibiani-Anhwiaso, Wassa Amenfi West, Sefwi Ankontombra, Bodi, and Juabeso political districts. It falls within the moist semideciduous ecological zone. The FRs inside the study area are colonized by dominant timber tree species such as Heretiera utilis, Cynometra ananta, and Celtis milbraedii, which have several medicinal and research purposes [24]. The FRs also provide natural habitats to mammals including the giant rat, the mona monkey, the red river hog, and Maxwell's duiker to name a few [24]. The inhabitants of the SWD have benefited from the timber utilization contracts (TUC) policy which include the development of schools, health facilities, and improved road networks. This has consequently improved income generation and increased the level of employment in the district [25].

A recent study in the southern part of Ahafo and the northern part of the Western North regions which contain the study area depicted an increasing rate of deforestation [13]. Primary and secondary forest loss had an annual rate of $1.9 \%$ over 25 years (1986-2011), but currently has an annual rate of $2.3 \%$ [13].

2.2. Landsat Imagery Preprocessing and Classification. The Landsat images used were from 1984, 1990, 1996, 2000, 2003, 2010, and 2017. Raw landsat imagery was acquired from the United States Geological Survey's (USGS) Earth Explorer using the SWD's area of interest (AOI). Instances of haze were removed through earth observation data repository. Histogram equalization was carried out in ArcGIS. Ground reference points representative of five land cover categories (Table 2), namely, close and open forest, farmland, grassland, and barelands used were collected. Band combinations 


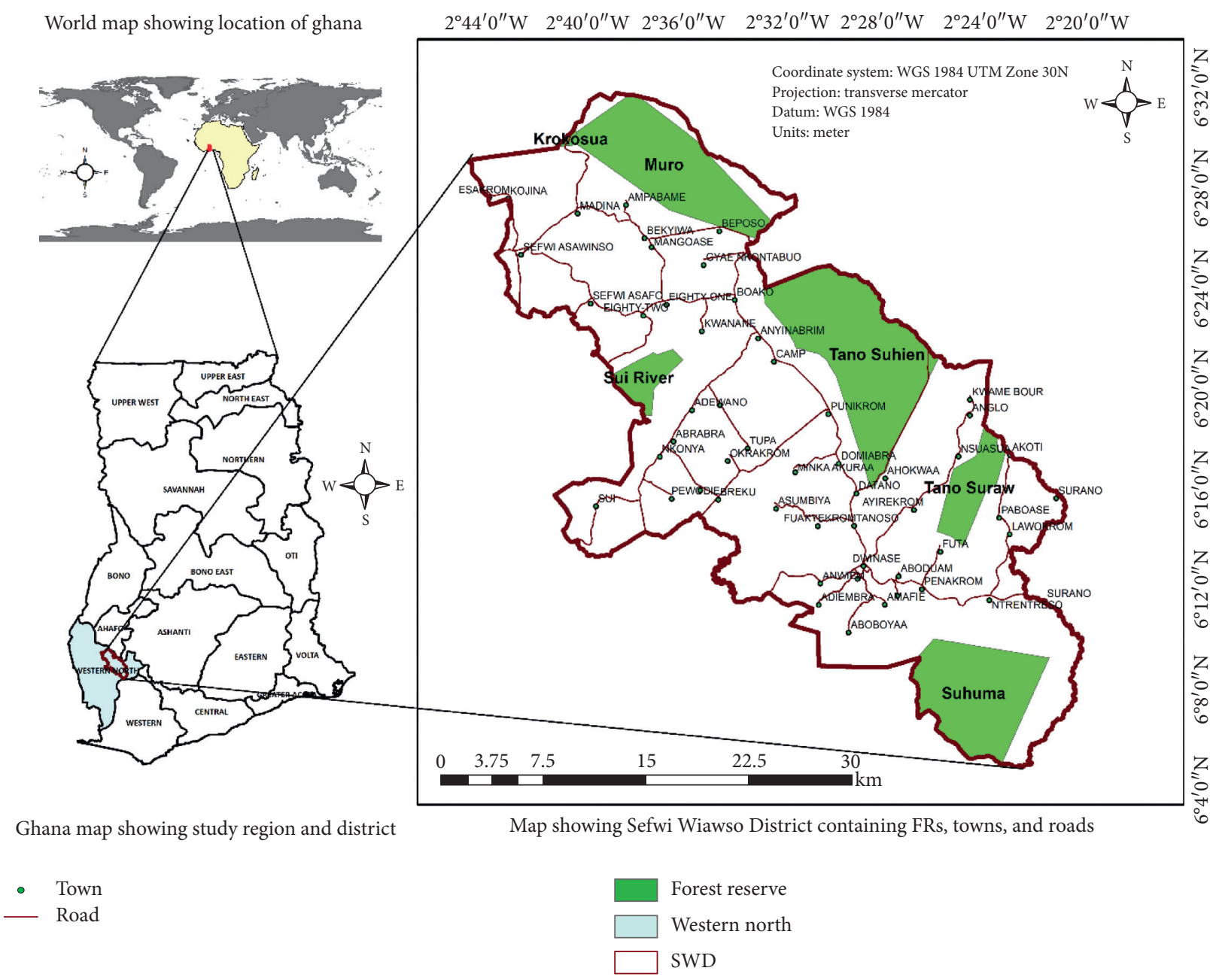

FIGURE 1: The SWD and the six forest reserves (FRs).

TABle 1: Areas (ha) and location of FRs within the SWD.

\begin{tabular}{|c|c|c|c|c|c|}
\hline \multicolumn{6}{|c|}{ Center point } \\
\hline Forest reserve & Size inside the study area (ha) & Latitude $(\mathrm{N})$ & Longitude $(\mathrm{W})$ & Forest type & Year reserved \\
\hline Krokosua & 100.35 & $6^{\circ} 30^{\prime} \mathrm{N}$ & $2^{\circ} 49^{\prime} \mathrm{W}$ & MSNW & 1935 \\
\hline Muro & 6489.2 & $6^{\circ} 29^{\prime} \mathrm{N}$ & $2^{\circ} 38^{\prime} \mathrm{W}$ & MSNW & 1951 \\
\hline Suhuma & 5975.08 & $6^{\circ} 04^{\prime} \mathrm{N}$ & $2^{\circ} 28^{\prime} \mathrm{W}$ & MSNW & 1935 \\
\hline Sui River & 1209.63 & $6^{\circ} 10^{\prime} \mathrm{N}$ & $2^{\circ} 44^{\prime} \mathrm{W}$ & $\mathrm{ME}$ & 1930 \\
\hline Tano Suhien & 9082.62 & $6^{\circ} 20^{\prime} \mathrm{N}$ & $2^{\circ} 28^{\prime} \mathrm{W}$ & MSNW & 1934 \\
\hline Tano Suraw & 1945.65 & $6^{\circ} 18^{\prime} \mathrm{N}$ & $2^{\circ} 18^{\prime} \mathrm{W}$ & MSSSE & 1934 \\
\hline
\end{tabular}

MSNW, moist semideciduous northwest subtype; MSSE, moist semideciduous southeast subtype; ME, moist evergreen [26].

(Table 3) for false color composites in Landsat 5 and Landsat 7 images were used to identify various land cover within the study area for better classification results [27]. The digital numbers (DNs) of the acquired imagery were subsequently sampled and trained using the Gaussian maximum likelihood classification algorithm (Figures 2 and 3). This algorithm was preferred because of the Bayes theorem decision-making, which accounts for some forest classes occurring in higher or lower pixel quantities than the average [28].
2.3. Accuracy Assessment. The study assessed the classifier's ability to accurately and quantitatively identify how efficient pixels were sampled into their correct land cover categories. A total of 350 geographically verified pixels (ground truths) were created on the images. These training samples were randomly assigned to each class and were proportional to the land cover sizes. Error matrix report tables for all LULC classifications (Tables 4 and 5) showed the relationships between ground truth data and the corresponding classified data [27]. Statistical accuracy metrics (Tables 6 and 7) which 
TABLe 2: Definitions of land cover categories [29, 30].

\begin{tabular}{lc}
\hline Land cover category & Characteristics \\
\hline Close forest & Light penetration forest floor $<25 \%(>75 \%$ canopy cover $)$ \\
Open forest & Light penetration forest floor $>25 \%(<75 \%$ canopy cover $)$ \\
Farmland & Commercial and subsistence agricultural land cover \\
Grassland & Open forest area replaced by dry or wet grass cover \\
Bareland & Settlement/cleared area with no forest regeneration ability \\
\hline
\end{tabular}

TABle 3: Satellite imagery information with color composites used.

\begin{tabular}{|c|c|c|c|c|}
\hline Date/Time & $\begin{array}{c}\text { Imagery } \\
\text { year }\end{array}$ & Satellite & $\begin{array}{c}\text { False color composite } \\
\text { used }\end{array}$ & Information \\
\hline $\begin{array}{l}14 / 12 / 1984 \\
\text { (day) }\end{array}$ & 1984 & Landsat 5 MSS & $(4,3,2)$ & Vegetation boundary between land, water, and landforms \\
\hline $\begin{array}{l}31 / 12 / 1990 \\
\text { (day) }\end{array}$ & 1990 & Landsat 5 TM & $(4,3,2),(5,4,3)$ & \\
\hline $\begin{array}{l}19 / 05 / 1995 \\
\text { (day) }\end{array}$ & 1995 & Landsat 5 TM & $(4,3,2),(5,4,3)$ & \\
\hline $\begin{array}{l}29 / 11 / 1996 \\
\text { (day) }\end{array}$ & 1996 & Landsat $5 \mathrm{TM}$ & $(4,3,2),(5,4,3)$ & \\
\hline $\begin{array}{l}2 / 2 / 2000 \\
\text { (day) }\end{array}$ & 2000 & $\begin{array}{c}\text { Landsat } 7 \\
\text { ETM+ }\end{array}$ & $(4,3,2),(5,4,3)$ & $\begin{array}{c}\text { Biomass content, peak and deciduous vegetation, and } \\
\text { differentiate vegetation slopes }\end{array}$ \\
\hline $\begin{array}{l}14 / 3 / 2003 \\
\text { (day) }\end{array}$ & 2003 & $\begin{array}{c}\text { Landsat } 7 \\
\text { ETM+ }\end{array}$ & $(4,3,2),(5,4,3),(7,5,3)$ & \\
\hline $\begin{array}{l}14 / 12 / 2010 \\
\text { (day) }\end{array}$ & 2010 & $\begin{array}{l}\text { Landsat } 7 \\
\text { ETM+ }\end{array}$ & $(4,3,2),(5,4,3),(7,5,3)$ & \\
\hline $\begin{array}{l}8 / 1 / 2017 \\
\text { (day) }\end{array}$ & 2017 & $\begin{array}{l}\text { Landsat } 7 \\
\text { ETM+ }\end{array}$ & $(4,3,2),(5,4,3),(7,5,3)$ & \\
\hline
\end{tabular}

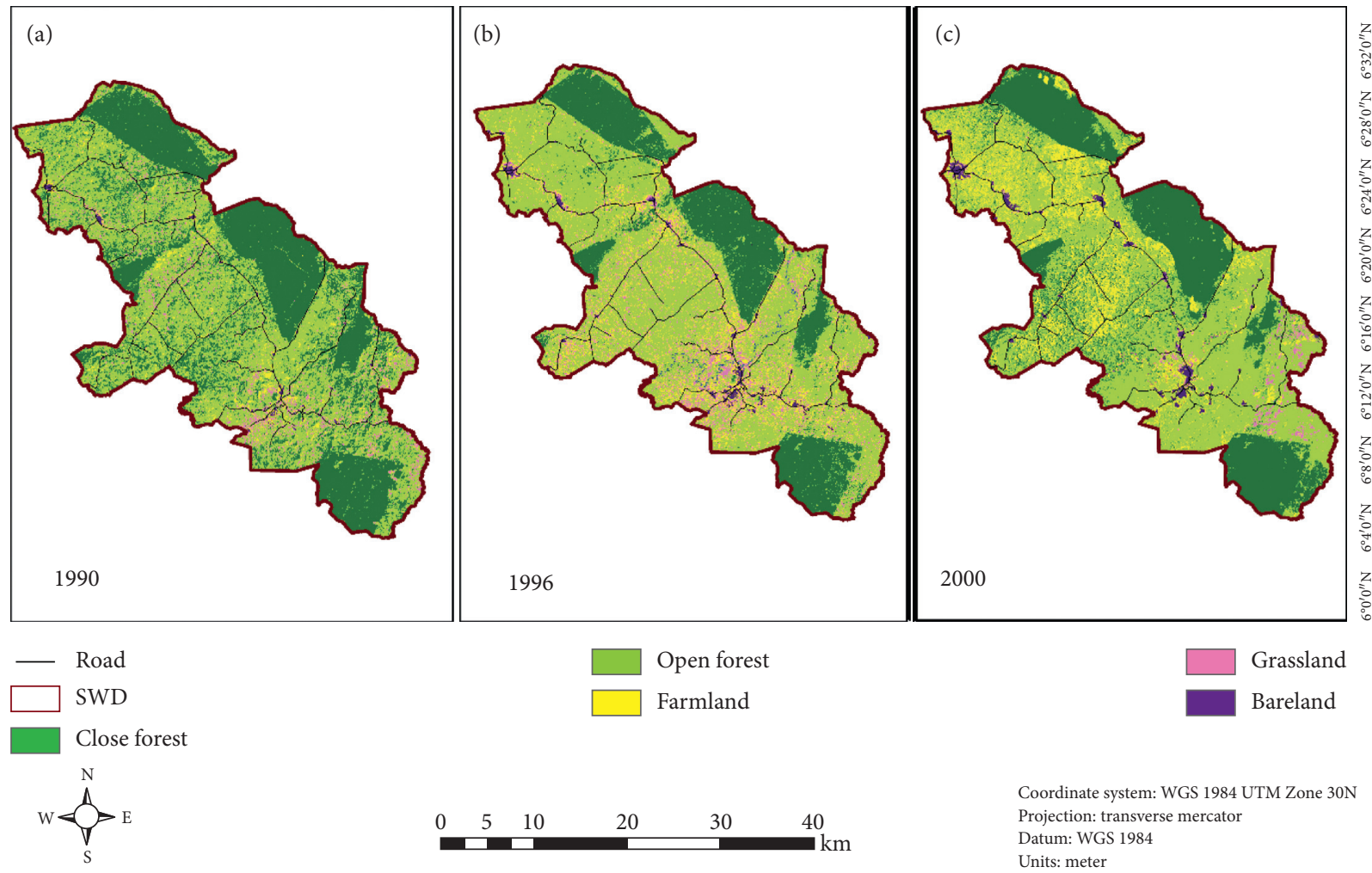

FIgURE 2: Classified SWD LULC image for (a) 1990; (b) 1996; and (c) 2000. 

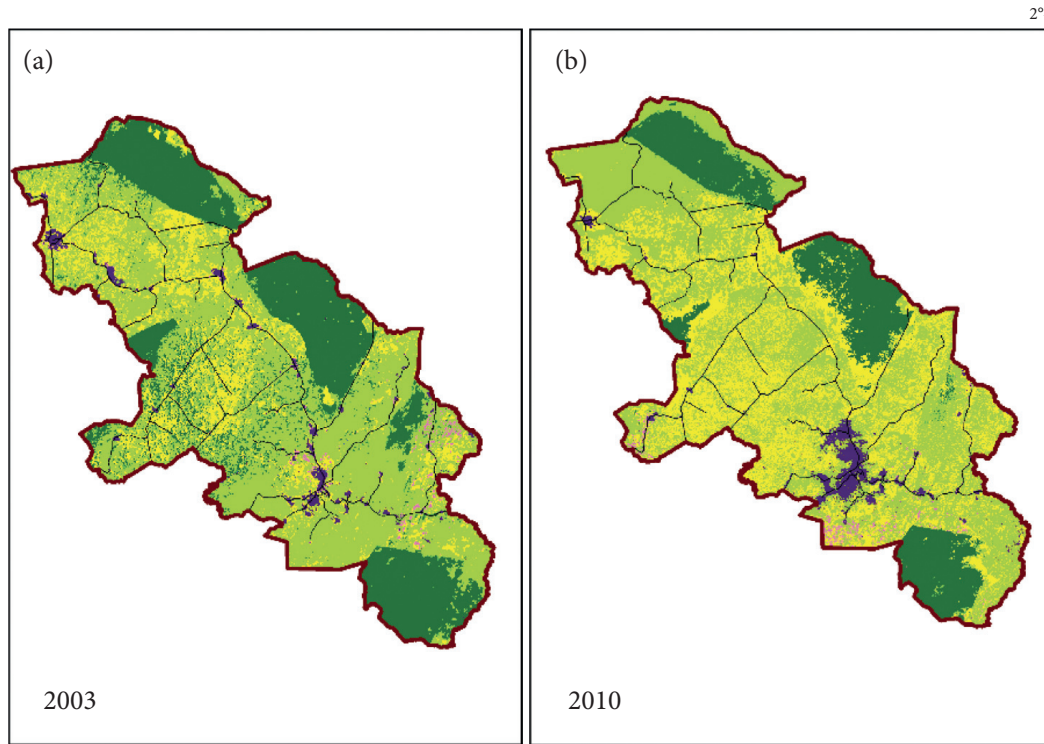

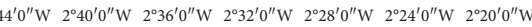
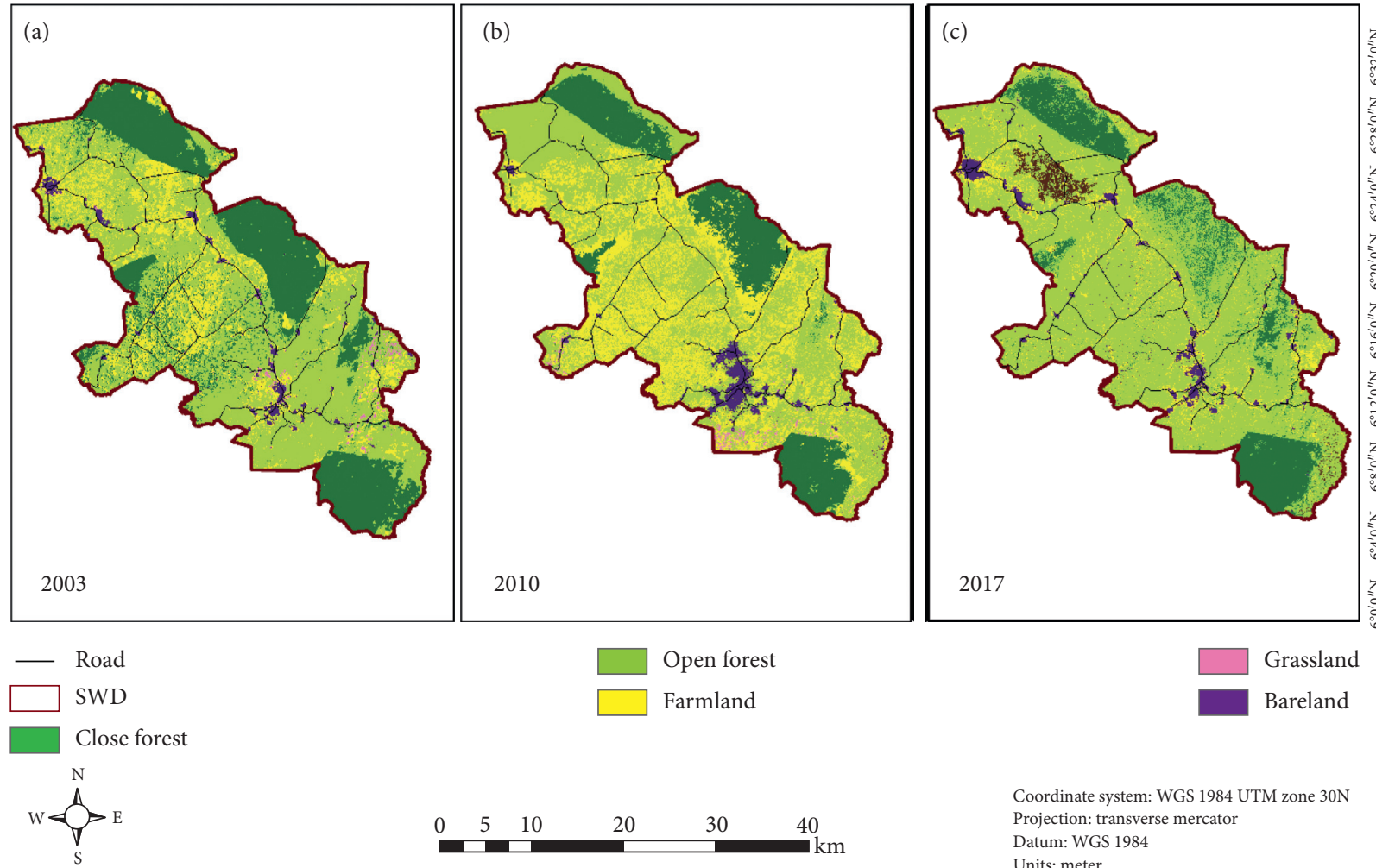

Figure 3: Classified SWD LULC image for (a) 2003; (b) 2010; and (c) 2017.

TABLE 4: Theoretical error matrix for 2017 LULC classification [32].

\begin{tabular}{|c|c|c|c|c|c|c|c|c|c|}
\hline \multicolumn{10}{|c|}{ Truth } \\
\hline S. No. & & Classified & Close forest & Open forest & Farmland & Grassland & Bareland & Total & Correct sampled \\
\hline \multirow{6}{*}{ Predicted } & 1 & Close forest & 63 & 3 & 2 & 0 & 5 & 73 & 63 \\
\hline & 2 & Open forest & 10 & 87 & 8 & 0 & 4 & 109 & 87 \\
\hline & 3 & Farmland & 5 & 3 & 64 & 2 & 7 & 81 & 64 \\
\hline & 4 & Grassland & 4 & 5 & 0 & 47 & 0 & 56 & 47 \\
\hline & 5 & Bareland & 3 & 5 & 4 & 1 & 18 & 31 & 18 \\
\hline & & Total & 85 & 103 & 78 & 50 & 34 & 350 & 279 \\
\hline
\end{tabular}

included commission and omission errors were also computed for all LULC classifications carried out [27, 31].

The columns (Table 4) show the classes in the validation (ground truth) pixel set, and the rows show the classified pixel sets. The overall accuracy which is the percentage of correctly classified points from the total number of points is $79 \%$ with a kappa of 0.738 .

\subsection{Analysis Using Forest Loss Instigators}

2.4.1. Road Proximity. Road shapefiles within the SWD were acquired and processed into three buffer distances. On-field verification coordinates and Google Earth Imagery were used to verify the current existence of road segments, junctions, and turns used in this study. The road segments used had a total distance of 271.20 kilometers. As a forest loss indicator, variable accessible road segments within FR areas raised red flags as they were suspected to expose the FRs to different forms of human interventions and deforestation risks [33]. The three road buffers set were based on proximity to FRs. High-, medium-, and low-risks identities were given to the road buffers based on the distance to FRs $[33,34]$. Referring to [34], this study devised a minimum distance interval (Table 8) for road buffers that would trigger early detection of forest loss in FRs. A workflow of road shapefile processing and subsequent LULC integration is shown in Figure 4.

2.4.2. Agricultural Expansion. Forest cover conversions between 2000 and 2017 were computed using change detection operators in the ArcGIS software. Change imageries between 2000 and 2010 and between 2010 and 2017 were generated. Highlight imagery was then used to visualize general land cover changes and nonchanges in FRs within the SWD (Figure 5). 
TABLE 5: Error matrix report tables for LULC classification.

\begin{tabular}{|c|c|c|c|c|c|c|c|c|c|}
\hline \multicolumn{10}{|c|}{ Truth } \\
\hline \multicolumn{2}{|l|}{ S. No. } & Classified & Close forest & Open forest & Farmland & Grassland & Bareland & Total & Correct sampled \\
\hline \multicolumn{10}{|c|}{ Theoretical error matrix for 1984 LULC classification } \\
\hline \multirow{6}{*}{ Predicted } & 1 & Close forest & 51 & 15 & 3 & 3 & 1 & 73 & 51 \\
\hline & 2 & Open forest & 22 & 73 & 4 & 6 & 4 & 109 & 73 \\
\hline & 3 & Farmland & 8 & 4 & 61 & 3 & 5 & 81 & 61 \\
\hline & 4 & Grassland & 9 & 3 & 4 & 37 & 3 & 56 & 37 \\
\hline & 5 & Bareland & 5 & 3 & 1 & 4 & 18 & 31 & 18 \\
\hline & & Total & 95 & 98 & 73 & 53 & 31 & 350 & 240 \\
\hline \multicolumn{10}{|c|}{ Theoretical error matrix for 1990 LULC classification } \\
\hline \multirow{6}{*}{ Predicted } & 1 & Close forest & 53 & 11 & 5 & 1 & 3 & 73 & 53 \\
\hline & 2 & Open forest & 15 & 69 & 15 & 4 & 6 & 109 & 69 \\
\hline & 3 & Farmland & 20 & 8 & 50 & 1 & 2 & 81 & 50 \\
\hline & 4 & Grassland & 10 & 5 & 4 & 32 & 5 & 56 & 32 \\
\hline & 5 & Bareland & 5 & 2 & 1 & 2 & 21 & 31 & 21 \\
\hline & & Total & 103 & 95 & 75 & 40 & 37 & 350 & 225 \\
\hline \multicolumn{10}{|c|}{ Theoretical error matrix for 1995 LULC classification } \\
\hline \multirow{6}{*}{ Predicted } & 1 & Close forest & 49 & 6 & 7 & 3 & 8 & 73 & 49 \\
\hline & 2 & Open forest & 10 & 83 & 5 & 4 & 7 & 109 & 83 \\
\hline & 3 & Farmland & 12 & 18 & 43 & 3 & 5 & 81 & 43 \\
\hline & 4 & Grassland & 12 & 10 & 7 & 19 & 8 & 56 & 19 \\
\hline & 5 & Bareland & 5 & 4 & 3 & 1 & 18 & 31 & 18 \\
\hline & & Total & 88 & 121 & 65 & 30 & 46 & 350 & 212 \\
\hline \multicolumn{10}{|c|}{ Theoretical error matrix for 1996 LULC classification } \\
\hline \multirow{6}{*}{ Predicted } & 1 & Close forest & 50 & 15 & 2 & 1 & 5 & 73 & 50 \\
\hline & 2 & Open forest & 19 & 81 & 6 & 2 & 1 & 109 & 81 \\
\hline & 3 & Farmland & 15 & 8 & 49 & 2 & 7 & 81 & 49 \\
\hline & 4 & Grassland & 7 & 16 & 4 & 25 & 4 & 56 & 25 \\
\hline & 5 & Bareland & 5 & 3 & 1 & 1 & 21 & 31 & 21 \\
\hline & & Total & 96 & 123 & 62 & 31 & 38 & 350 & 226 \\
\hline \multicolumn{10}{|c|}{ Theoretical error matrix for 1995 LULC classification } \\
\hline \multirow{6}{*}{ Predicted } & 1 & Close forest & 50 & 15 & 2 & 1 & 5 & 73 & 50 \\
\hline & 2 & Open forest & 19 & 81 & 6 & 2 & 1 & 109 & 81 \\
\hline & 3 & Farmland & 15 & 8 & 49 & 2 & 7 & 81 & 49 \\
\hline & 4 & Grassland & 7 & 16 & 4 & 25 & 4 & 56 & 25 \\
\hline & 5 & Bareland & 5 & 3 & 1 & 1 & 21 & 31 & 21 \\
\hline & & Total & 96 & 123 & 62 & 31 & 38 & 350 & 226 \\
\hline \multicolumn{10}{|c|}{ Theoretical error matrix for 2000 LULC classification } \\
\hline \multirow{6}{*}{ Predicted } & 1 & Close forest & 64 & 4 & 3 & 1 & 1 & 73 & 64 \\
\hline & 2 & Open forest & 6 & 89 & 10 & 1 & 3 & 109 & 89 \\
\hline & 3 & Farmland & 11 & 18 & 41 & 4 & 7 & 81 & 41 \\
\hline & 4 & Grassland & 7 & 16 & 4 & 25 & 4 & 56 & 25 \\
\hline & 5 & Bareland & 1 & 2 & 1 & 3 & 24 & 31 & 24 \\
\hline & & Total & 89 & 129 & 59 & 34 & 39 & 350 & 243 \\
\hline \multicolumn{10}{|c|}{ Theoretical error matrix for 2003 LULC classification } \\
\hline & 1 & Close forest & 55 & 5 & 2 & 5 & 6 & 73 & 55 \\
\hline & 2 & Open forest & 13 & 85 & 5 & 4 & 2 & 109 & 85 \\
\hline Predicted & 3 & Farmland & 11 & 3 & 63 & 3 & 1 & 81 & 63 \\
\hline Predicted & 4 & Grassland & 6 & 10 & 3 & 35 & 2 & 56 & 35 \\
\hline & 5 & Bareland & 5 & 2 & 2 & 3 & 19 & 31 & 19 \\
\hline & & Total & 90 & 105 & 75 & 50 & 30 & 350 & 257 \\
\hline Theoretica & rror & matrix for 2010 & ULC classific & & & & & & \\
\hline & 1 & Close forest & 54 & 2 & 8 & 6 & 3 & 73 & 54 \\
\hline & 2 & Open forest & 14 & 78 & 3 & 6 & 8 & 109 & 78 \\
\hline & 3 & Farmland & 10 & 21 & 40 & 6 & 4 & 81 & 40 \\
\hline Predicted & 4 & Grassland & 9 & 12 & 4 & 21 & 10 & 56 & 21 \\
\hline & 5 & Bareland & 4 & 2 & 1 & 3 & 21 & 31 & 21 \\
\hline & & Total & 91 & 115 & 56 & 42 & 46 & 350 & 214 \\
\hline
\end{tabular}


TABLE 6: Accuracy assessment statistical parameters for 2017 land use land cover (LULC) [32].

\begin{tabular}{lcccc}
\hline Classified data & Commission error & Omission error & User's accuracy & Producer's accuracy \\
\hline Close forest & 0.1370 & 0.2588 & 0.8630 & 0.7412 \\
Open forest & 0.2018 & 0.1553 & 0.7982 & 0.8447 \\
Farmland & 0.2099 & 0.1795 & 0.7901 & 0.8205 \\
Grassland & 0.1607 & 0.0600 & 0.8393 & 0.9400 \\
Bareland & 0.4194 & 0.4706 & 0.5806 & 0.5294 \\
\hline
\end{tabular}

TABle 7: Accuracy assessment statistical parameters for LULC classification.

\begin{tabular}{|c|c|c|c|c|}
\hline Classified data & Commission error & Omission error & User's accuracy & Producer's accuracy \\
\hline \multicolumn{5}{|c|}{ Accuracy assessment statistical parameters for 1984 LULC. Overall accuracy is $69 \%$ with a kappa of 0.595} \\
\hline Close forest & 0.3014 & 0.4632 & 0.6986 & 0.5368 \\
\hline Open forest & 0.3303 & 0.2551 & 0.6697 & 0.7449 \\
\hline Farmland & 0.2469 & 0.1644 & 0.7531 & 0.8356 \\
\hline Grassland & 0.3393 & 0.3019 & 0.6607 & 0.6981 \\
\hline Bareland & 0.4194 & 0.4194 & 0.5806 & 0.5806 \\
\hline \multicolumn{5}{|c|}{ Accuracy assessment statistical parameters for 1990 LULC. Overall accuracy is $64 \%$ with a kappa of 0.540} \\
\hline Close forest & 0.2740 & 0.4854 & 0.7260 & 0.5146 \\
\hline Open forest & 0.3670 & 0.2737 & 0.6330 & 0.7263 \\
\hline Farmland & 0.3827 & 0.3333 & 0.6173 & 0.6667 \\
\hline Grassland & 0.4286 & 0.2000 & 0.5714 & 0.8000 \\
\hline Bareland & 0.3226 & 0.4324 & 0.6774 & 0.5676 \\
\hline \multicolumn{5}{|c|}{ Accuracy assessment statistical parameters for 1995 LULC. Overall accuracy is $61 \%$ with a kappa of 0.489} \\
\hline Close forest & 0.3288 & 0.4432 & 0.6712 & 0.5568 \\
\hline Open forest & 0.2385 & 0.3140 & 0.7615 & 0.6860 \\
\hline Farmland & 0.4691 & 0.3385 & 0.5309 & 0.6615 \\
\hline Grassland & 0.6607 & 0.3667 & 0.3393 & 0.6333 \\
\hline Bareland & 0.4194 & 0.6087 & 0.5806 & 0.3913 \\
\hline \multicolumn{5}{|c|}{ Accuracy assessment statistical parameters for 1996 LULC. Overall accuracy is $65 \%$ with a kappa of 0.539} \\
\hline Close forest & 0.3151 & 0.4792 & 0.6849 & 0.5208 \\
\hline Open forest & 0.2569 & 0.3415 & 0.7431 & 0.6585 \\
\hline Farmland & 0.3951 & 0.2097 & 0.6049 & 0.7903 \\
\hline Grassland & 0.5536 & 0.1935 & 0.4464 & 0.8065 \\
\hline Bareland & 0.3226 & 0.4474 & 0.6774 & 0.5526 \\
\hline \multicolumn{5}{|c|}{ Accuracy assessment statistical parameters for 2000 LULC. Overall accuracy is $69 \%$ with a kappa of 0.602} \\
\hline Close forest & 0.1233 & 0.2809 & 0.8767 & 0.7191 \\
\hline Open forest & 0.1835 & 0.3101 & 0.8165 & 0.6899 \\
\hline Farmland & 0.4938 & 0.3051 & 0.5062 & 0.6949 \\
\hline Grassland & 0.5536 & 0.2647 & 0.4464 & 0.7353 \\
\hline Bareland & 0.2258 & 0.3846 & 0.7742 & 0.6154 \\
\hline \multicolumn{5}{|c|}{ Accuracy assessment statistical parameters for 2003 LULC. Overall accuracy is $73 \%$ with a kappa of 0.656} \\
\hline Close forest & 0.2466 & 0.3889 & 0.7534 & 0.6111 \\
\hline Open forest & 0.2202 & 0.1905 & 0.7798 & 0.8095 \\
\hline Farmland & 0.2222 & 0.1600 & 0.7778 & 0.8400 \\
\hline Grassland & 0.3750 & 0.3000 & 0.6250 & 0.7000 \\
\hline Bareland & 0.3871 & 0.3667 & 0.6129 & 0.6333 \\
\hline \multicolumn{5}{|c|}{ Accuracy assessment statistical parameters for 2010 LULC. Overall accuracy is $61 \%$ with a kappa of 0.499} \\
\hline Close forest & 0.2603 & 0.4066 & 0.7397 & 0.5934 \\
\hline Open forest & 0.2844 & 0.3217 & 0.7156 & 0.6783 \\
\hline Farmland & 0.5062 & 0.2857 & 0.4938 & 0.7143 \\
\hline Grassland & 0.6250 & 0.5000 & 0.3750 & 0.5000 \\
\hline Bareland & 0.3226 & 0.5435 & 0.6774 & 0.4565 \\
\hline
\end{tabular}

TABLE 8: Illegal disturbance risk level categories.

\begin{tabular}{lcc}
\hline Risk level & Risk defined & Color code \\
\hline High & Reserves boundary within $1 \mathrm{~km}$ of a trunk/feeder road & Red \\
Medium & Reserves boundary between $1 \mathrm{~km}$ and $2 \mathrm{~km}$ distance from a trunk/feeder road & Blue \\
Low & Reserves boundary between $2 \mathrm{~km}$ and $3 \mathrm{~km}$ and above distance from a trunk/feeder road & Black \\
\hline
\end{tabular}




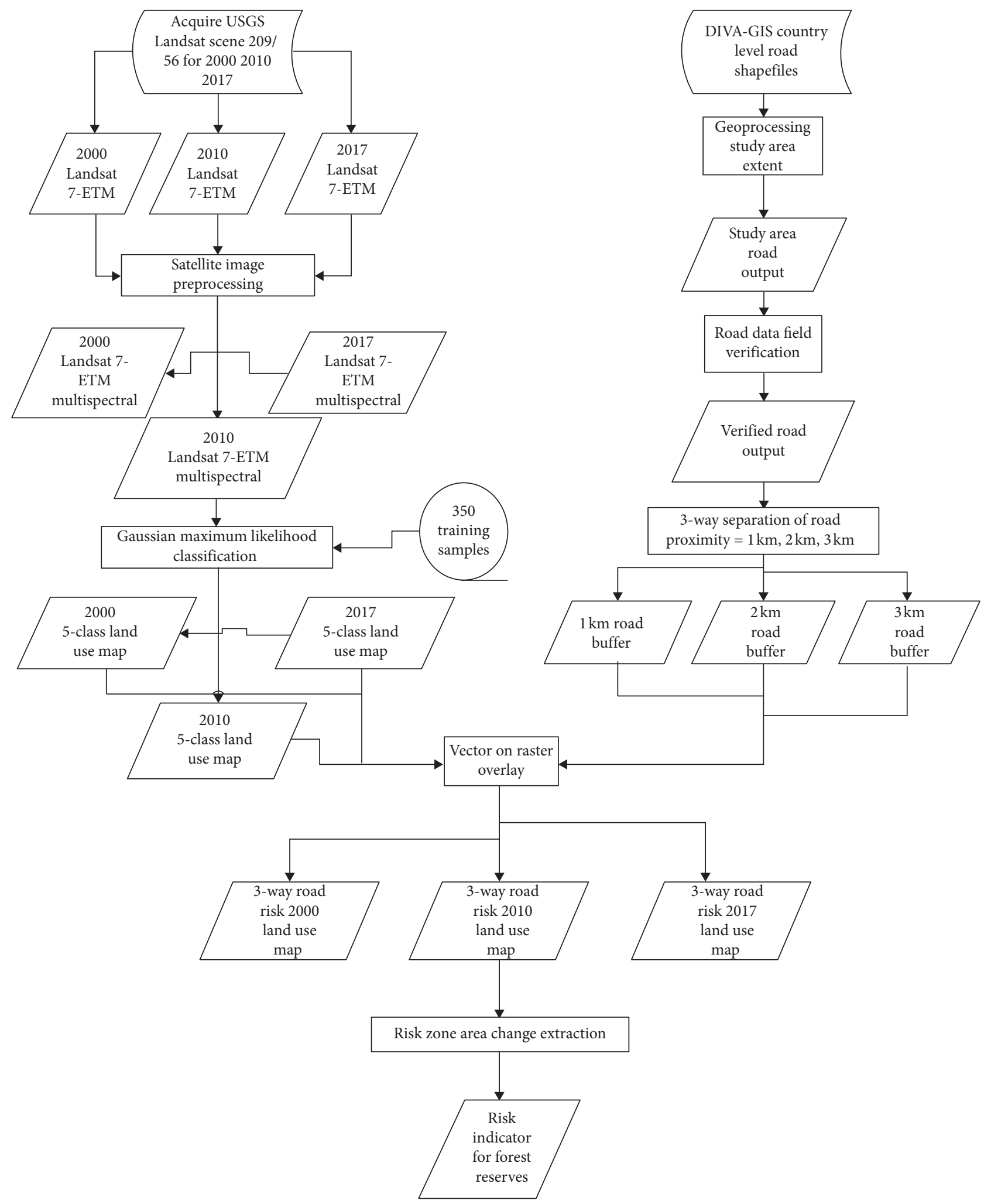

FIgURE 4: A workflow of road shapefile processing and subsequent LULC integration.

2.4.3. Community Density. The location density of communities within the SWD was in focus in this section. The study selected the FRs that were more susceptible to unlawful intrusions based on proximity to high-intensity community clusters. The FRs were ranked according to the level of danger posed by intense community locations through the forest area in hectares (ha) disturbances revealed by LULC classification results. Community 


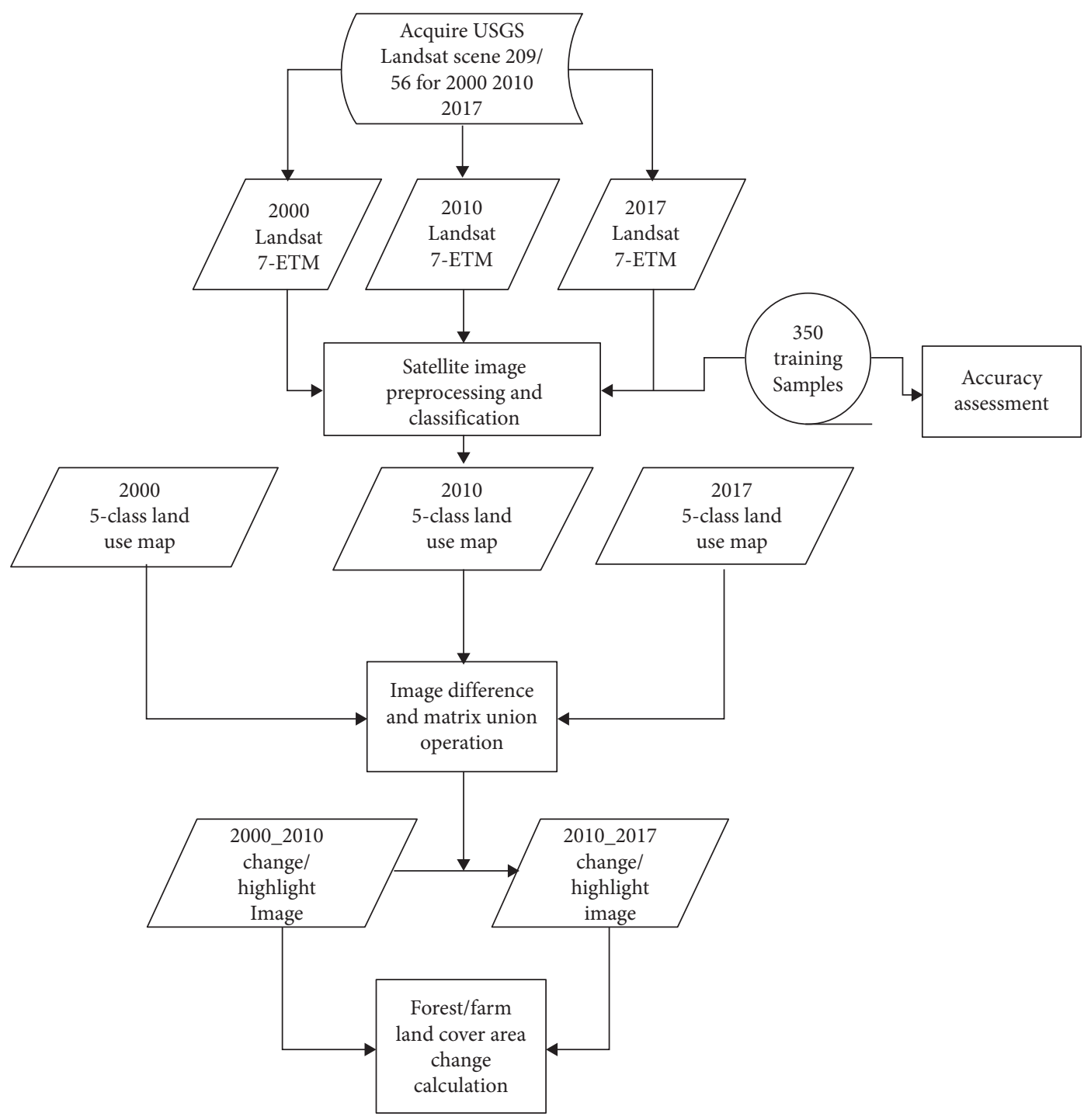

Figure 5: Workflow for farmland change detection.

shapefiles for the SWD were acquired and used for the analysis. Eight hundred and ninety-six forest fringe communities were spatially verified and found to be within the SWD. A density raster created from the community point shapefiles was used for spatial autocorrelation [35]. Communities whose boundaries coincided with each other were integrated through a specified $X Y$ tolerance [35]. The point density radius of the communities within the SWD was computed through repeated spatial autocorrelation. Random distance values were compared to the corresponding $z$ scores, and a line graph was created to measure the peak $z$ score [35]. The $z$-score recorded the intensity of community clustering. A community density raster (Figure 6) was calculated and integrated into the LULC dataset (Figure 7).

2.5. Simple Moving Averages the LULC Forecasting Model. Predicting the pixel area conversions for 2020 and 2024 LULC was achieved with the simple moving averages
(SMA) forecasting model [36]. The model calculates a current image average by adding recent changes and dividing by the number of periods in the calculation average [36]. The mean absolute deviation (MAD) was calculated for each average between two selected years. The cell information (Figure 8) of the image was extracted and counted for each class. The pixel area (PA) per class was determined by multiplying the width of image resolution by the cells count per class. Pixel areas for each category were extracted after average prediction and used for the arithmetic. The pixel area (PA) of the classified imagery for the years 1990, 1995, 1996, 2000, 2003, 2010, and 2017 were used to predict 2020 and 2024 LULC imagery. The predicted land cover year was calculated by averaging the previous two years separated by the same interval if major LULC changes were expected within that timestamp [1]. An example is shown in equation (1) for predicting the pixel area for 2010 LULC. The error between a predicted year and 


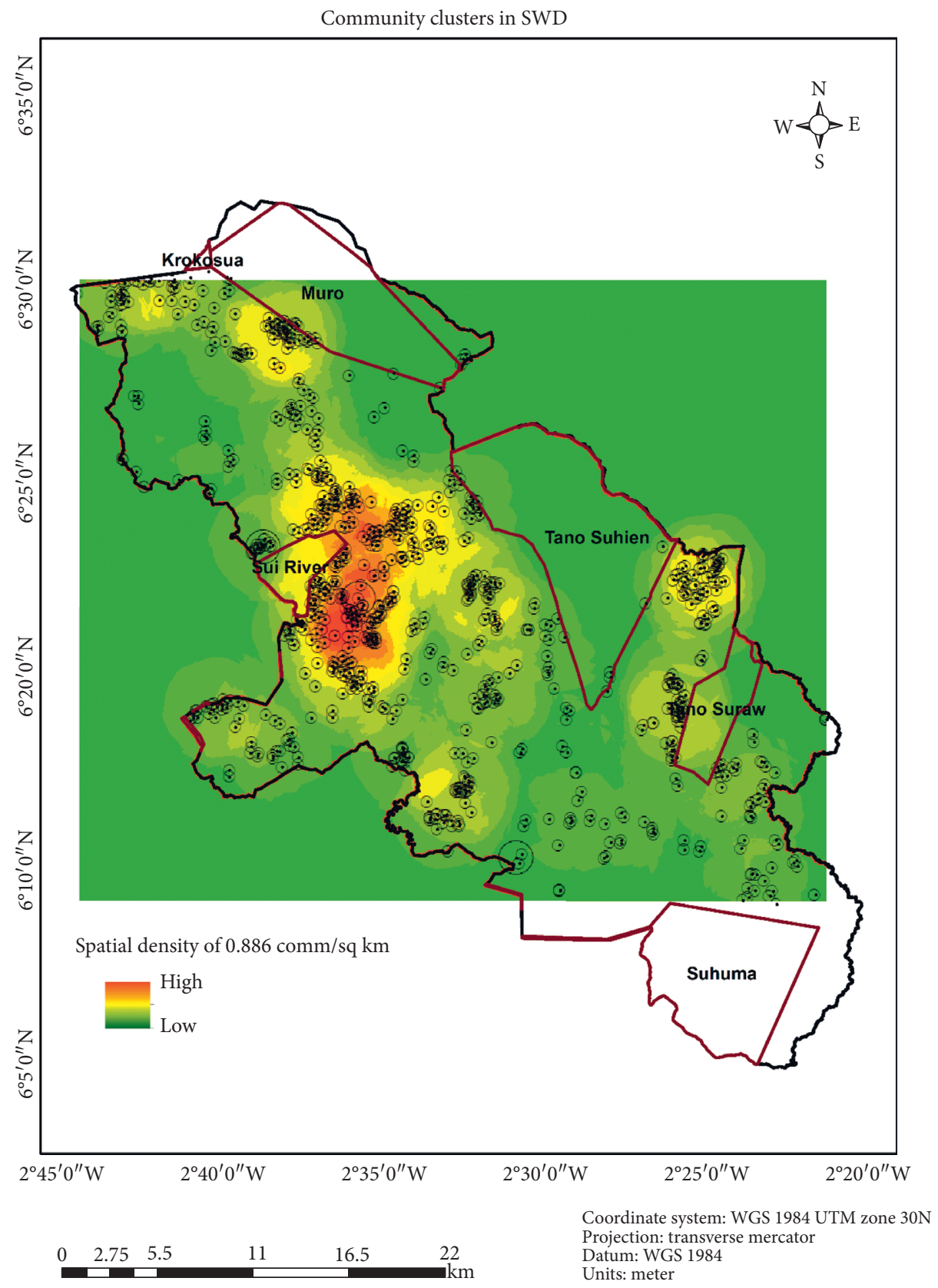

FIGURE 6: A community density raster created through spatial autocorrelation.

the original land cover is seen in equation (2) and catered for by the MAD calculated in equation (3). LULC for 2020 and 2024 is calculated in equations (4) and (5).

$$
2010 \mathrm{PPA}=\frac{1990 \mathrm{PA}+2000 \mathrm{PA}}{2},
$$

$$
\text { Err2010PPA }=|(2010 P A-2010 P P A)|,
$$

$$
\mathrm{MAD}=\frac{|(2010 \mathrm{PA}-2010 \mathrm{PPA})|+|(2017 \mathrm{PA}-2017 \mathrm{PPA})|}{2},
$$

$$
\text { 2024PA }=\text { Err2017PA }+ \text { MAD, }
$$

where PA is the pixel area of the classified image, PPA is the predicted pixel area of the classified image, Err is the error between the original and predicted forest land cover pixel areas, and MAD is the mean absolute deviation. The forecasting method was based on the assumption that past trends in forest loss will continue in the future.

(i) Cell counts per class used in calculating the pixel area per class and performing pixel arithmetic between categorical LULC classes

(ii) Two time stamps used in calculating the predicted pixel area for equal interval time points 


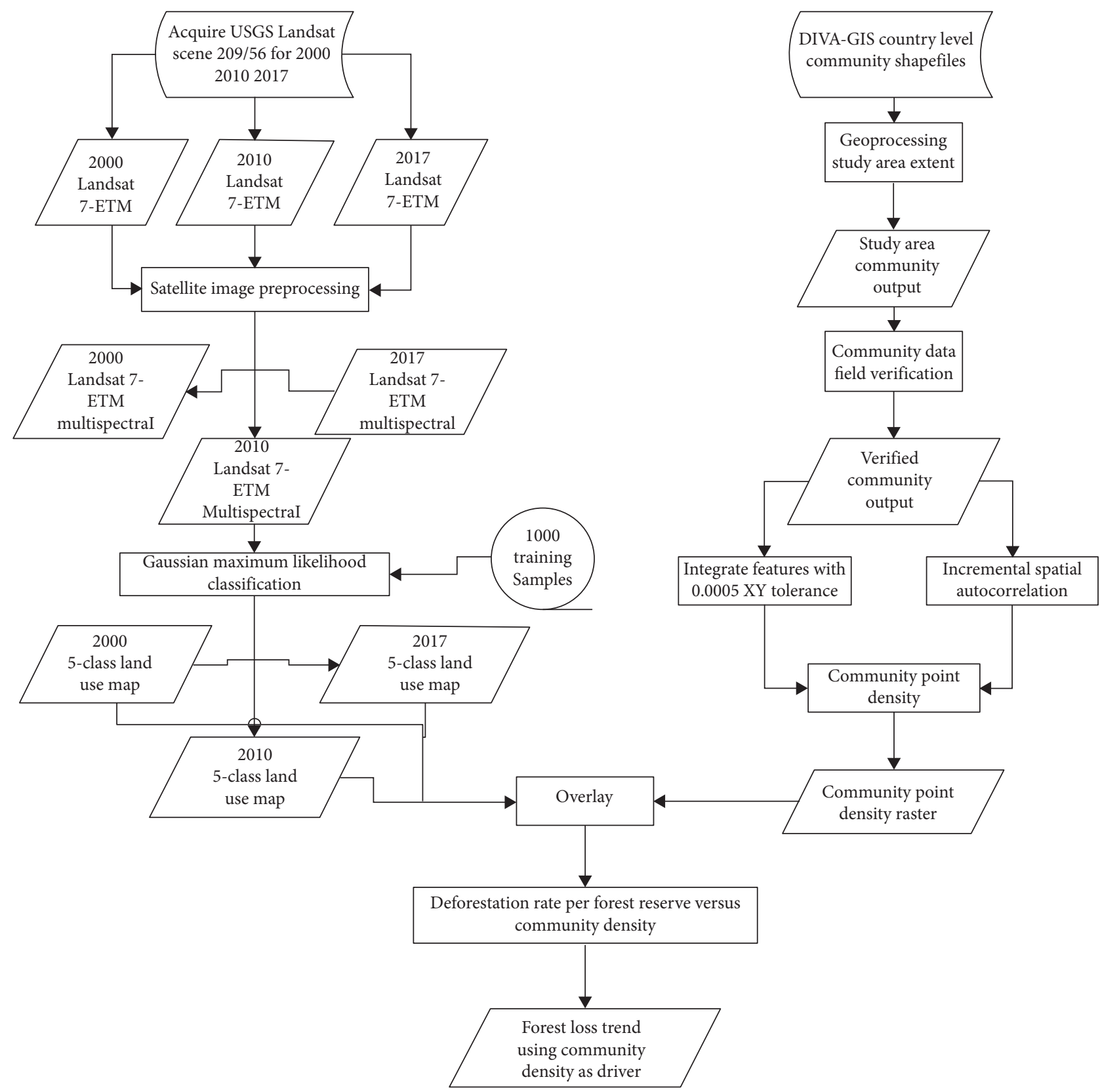

FIgURE 7: A workflow of community shapefile processing and subsequent LULC integration.

(iii) (Shown yellow) Predicted pixel area and original pixel area for a time interval used to calculate the mean absolute deviation and predicted pixel area error

(iv) Predicted pixel area for 2024 using the predicted pixel area error and mean absolute deviation

\section{Results}

3.1. Road Proximity Impact. After the integration of LULC with road buffer datasets, the risk status of the FRs was visualized (Figure 9 and Table 9). Muro, Tano Suhien, Tano Suraw, Krokosua, and Sui River FRs were more susceptible to intrusions through accessibility compared to Suhuma FR.
Muro FR showed a rise in close forest cover by 165.1 hectares (ha) from 2000 to 2010 but a reduction by 116.36 hectares (ha) in close forest cover by 2017. Close forest cover in Tano Suhien FR forest showed a reduction from 2000 to 2017 by 1476.11 hectares (ha) (Figure 10). Farmland cover in Tano Suhien FR showed an increase to 1850.00 hectares (ha) from 2010 to 2017. In Tano Suraw FR, close forest cover reduced by 1297.73 hectares (ha) from 2000 to 2017, whereas farmland cover increased from 9.18 hectares (ha) in 2000 to 292.61 hectares (ha) in 2017. In Sui River FR, close forest reduced by 396.31 hectares (ha) from 2000 to 2017, whereas farmland cover increased again by 494.04 hectares (ha) within the same period. In Suhuma FR, close forest cover increased by 4.11 hectares (ha) from 2000 to 2017. 


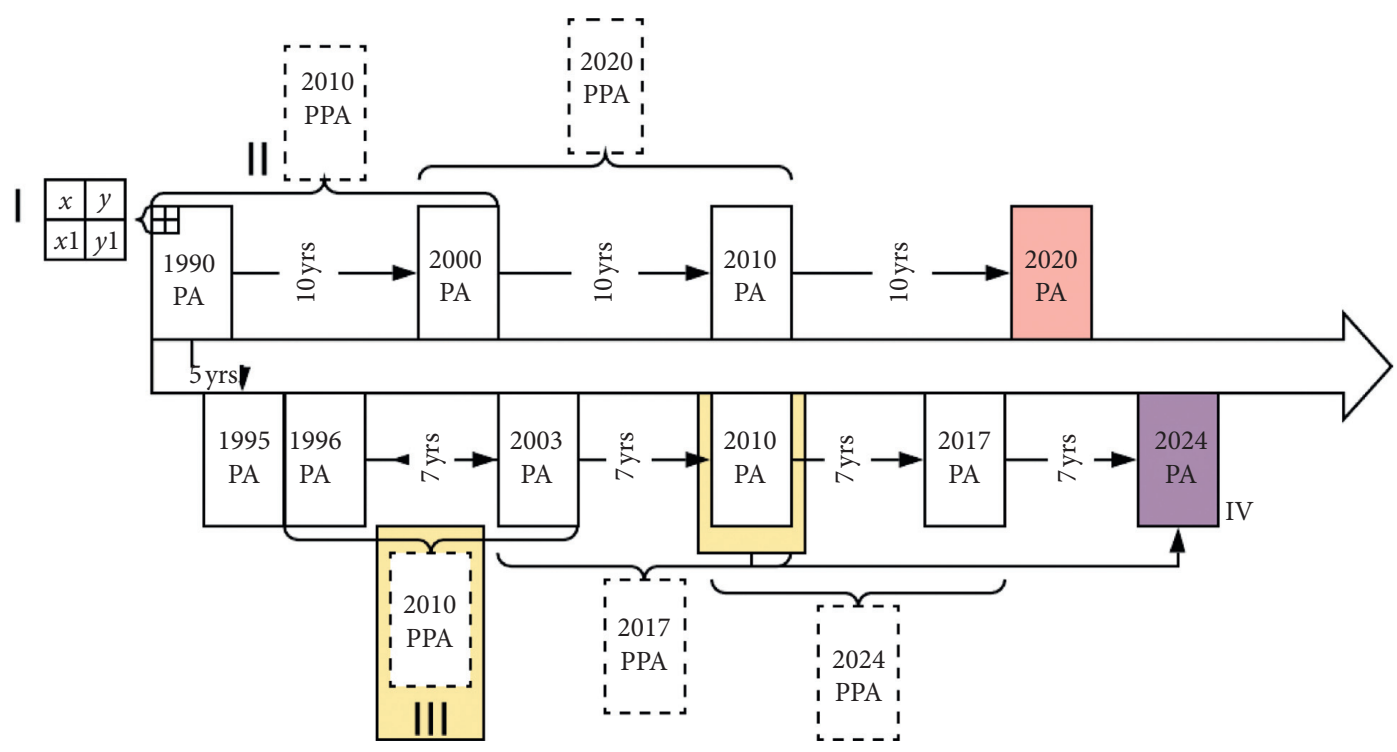

FIGURE 8: Illustrated flow of the SMA forecasting model on LULC imagery.

Map showing 3 road buffers generated in the swd
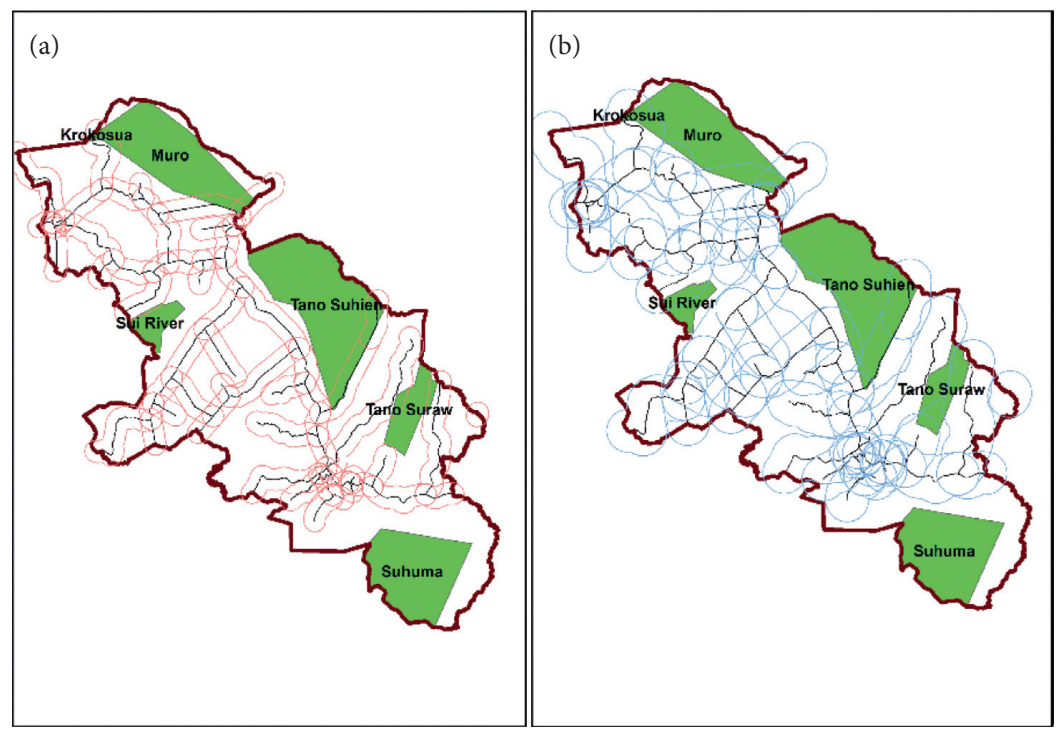

$2^{\circ} 44^{\prime} 0^{\prime \prime} \mathrm{W} \quad 2^{\circ} 40^{\prime} 0^{\prime \prime} \mathrm{W} \quad 2^{\circ} 36^{\prime} 0^{\prime \prime} \mathrm{W} \quad 2^{\circ} 32^{\prime} 0^{\prime \prime} \mathrm{W} \quad 2^{\circ} 28^{\prime} 0^{\prime \prime} \mathrm{W} \quad 2^{\circ} 24^{\prime} 0^{\prime \prime} \mathrm{W} \quad 2^{\circ} 20^{\prime} 0^{\prime \prime} \mathrm{W}$
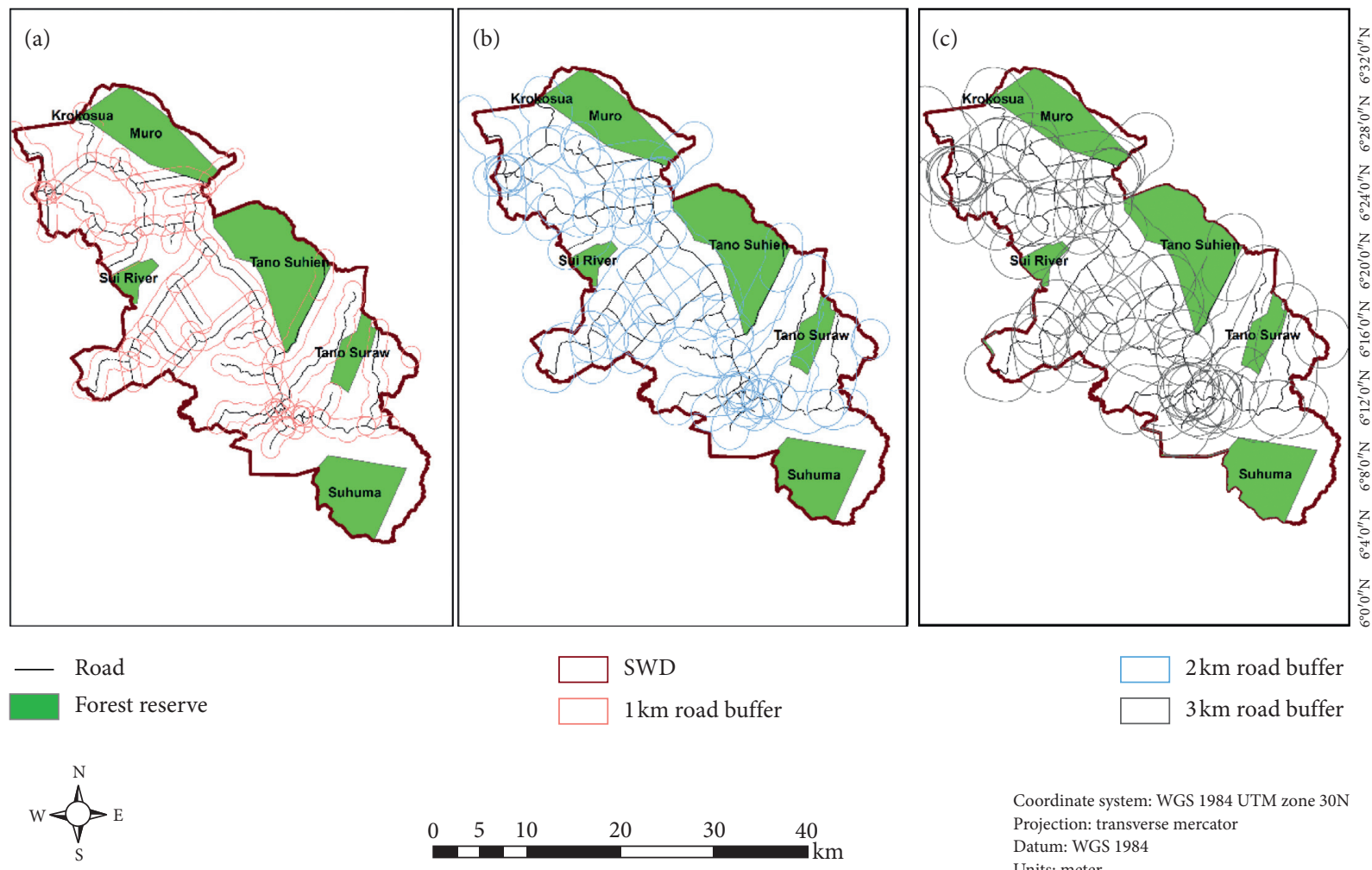

F

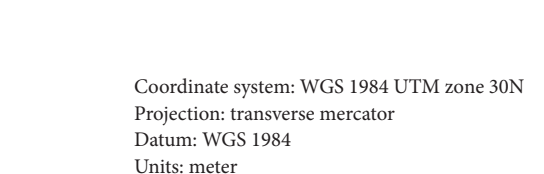

Figure 9: Road buffer overlay on FRs in SWD: (a) $1 \mathrm{~km}$; (b) $2 \mathrm{~km}$; and (c) $3 \mathrm{~km}$.

3.2. Impact of Agricultural Expansion. LULC change and highlight imagery showed locations and intensity of forest cover conversions from 2000 to 2017 (Figure 11). Significant conversions from forest to other land covers occurred between 2000 and 2010 and then between 2010 and 2017 (Table 10). A total of 240.84 hectares (ha) of close forest cover was converted to farmland cover from 2000 to 2010 in all six FRs (Table 11). The relatively low area conversion was due to intensive and enhanced community involvement in sustainable forest management particularly in Krokosua FR [37]. Open forest cover area of 141.39 hectares (ha) was converted to farmland cover from 2000 to 2010. Open forest cover area of 1313.28 hectares (ha) was converted to close forest cover, and 2321.46 hectares (ha) of close forest cover 
TABLE 9: Risk Status of the FRs based on road buffer proximity.

\begin{tabular}{lcccc}
\hline & & Risk level & & \\
Forest reserve & High & Medium & Low \\
\hline Muro & $\times$ & - & - \\
Krokosua & $\times$ & - & - \\
Tano Suhien & $\times$ & - & $\times$ \\
Suhuma & - & - & - \\
Sui River & $\times$ & - & - \\
Tano Suraw & $\times$ & & \\
\hline
\end{tabular}

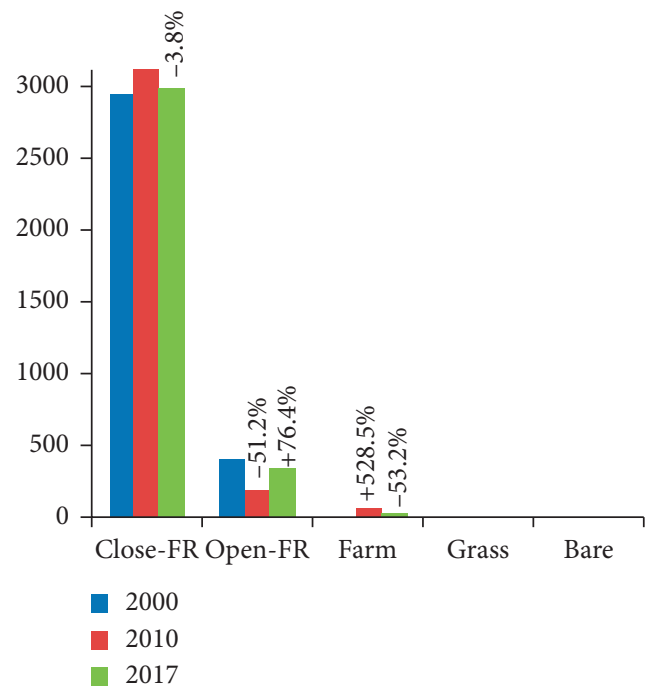

(a)

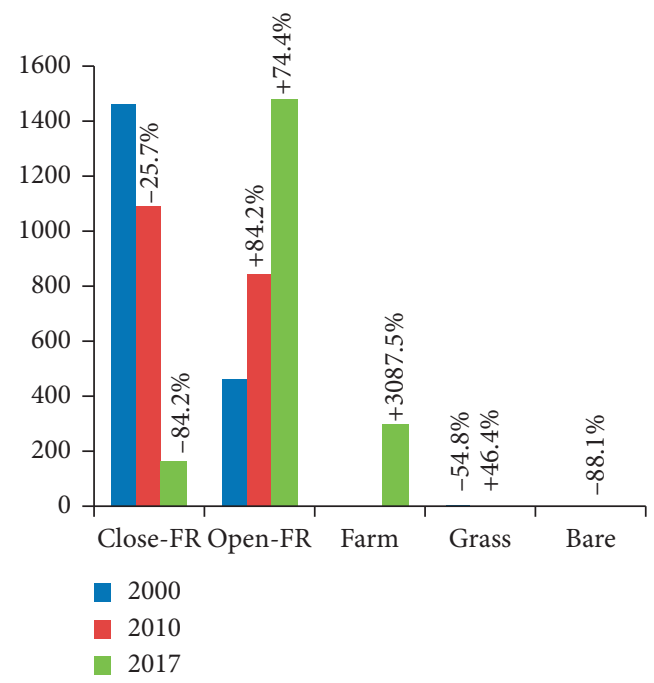

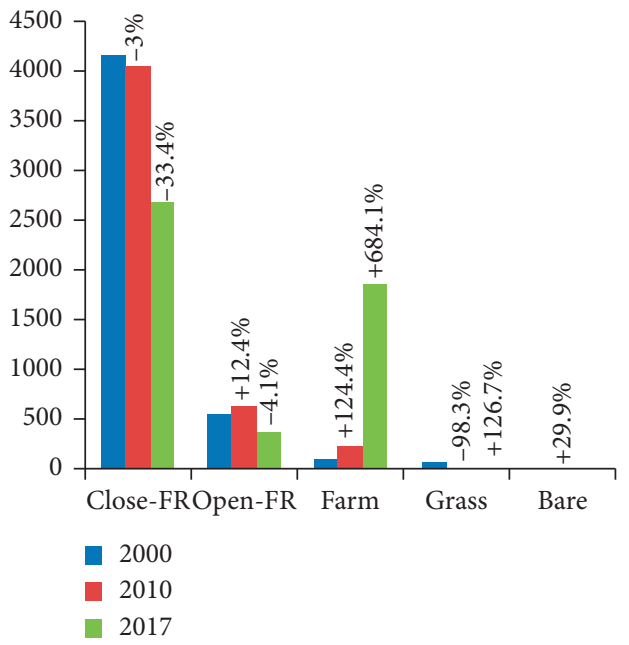

(b)

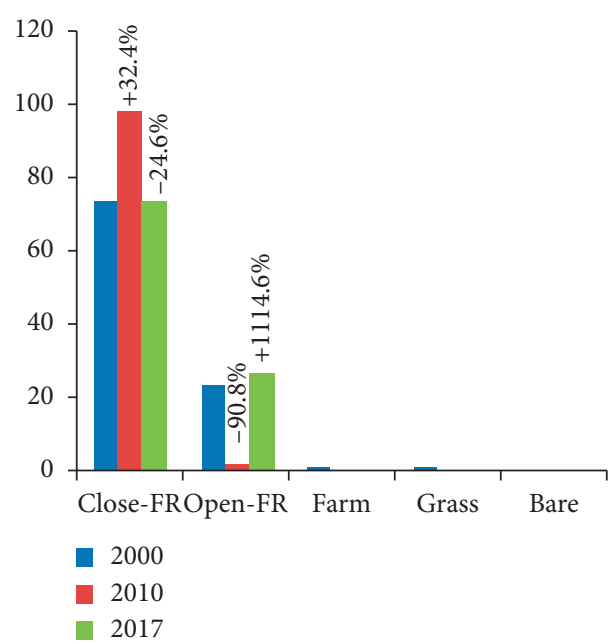

(d)

FIGURE 10: Continued. 


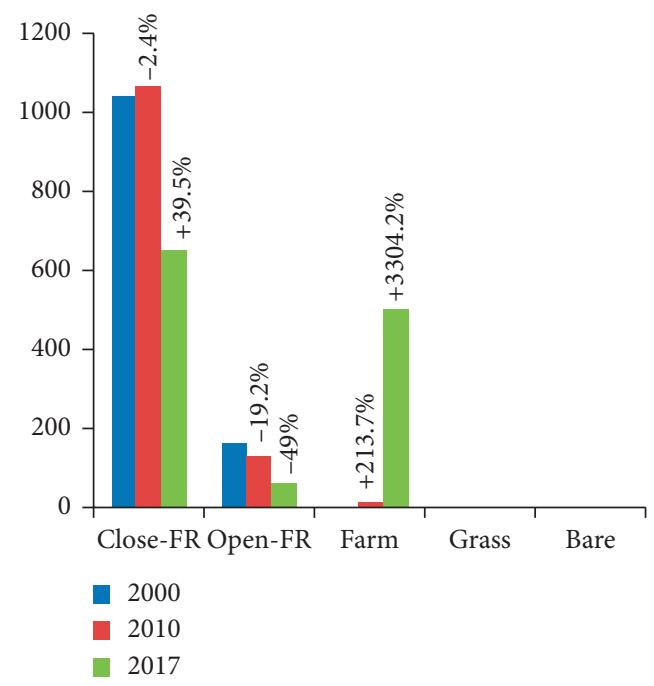

(e)

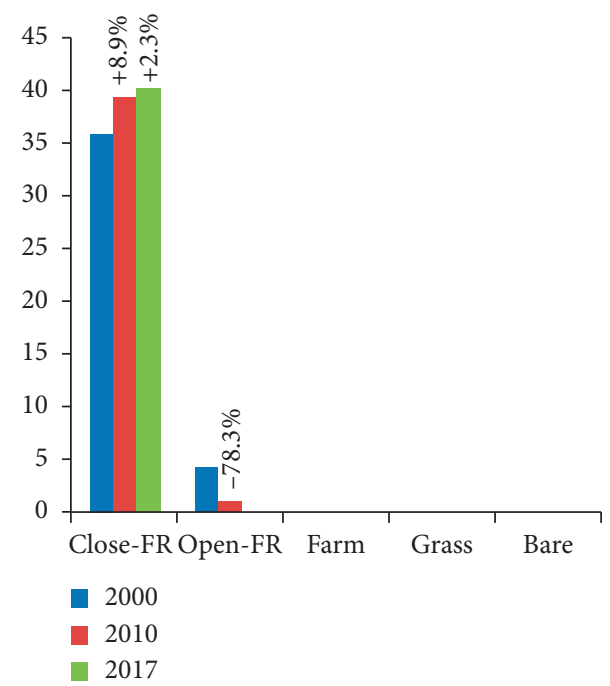

(f)

FiguRe 10: Forest land cover trends (\% increase/decrease) for six FRs based on road proximity: (a) Muro FR; (b) Tano Suhien FR; (c) Tano Suraw FR; (d) Krokosua FR; (e) Sui River FR; and (f) Suhuma FR.

Forest to farmland conversion for 2000 to 2010 and 20102017

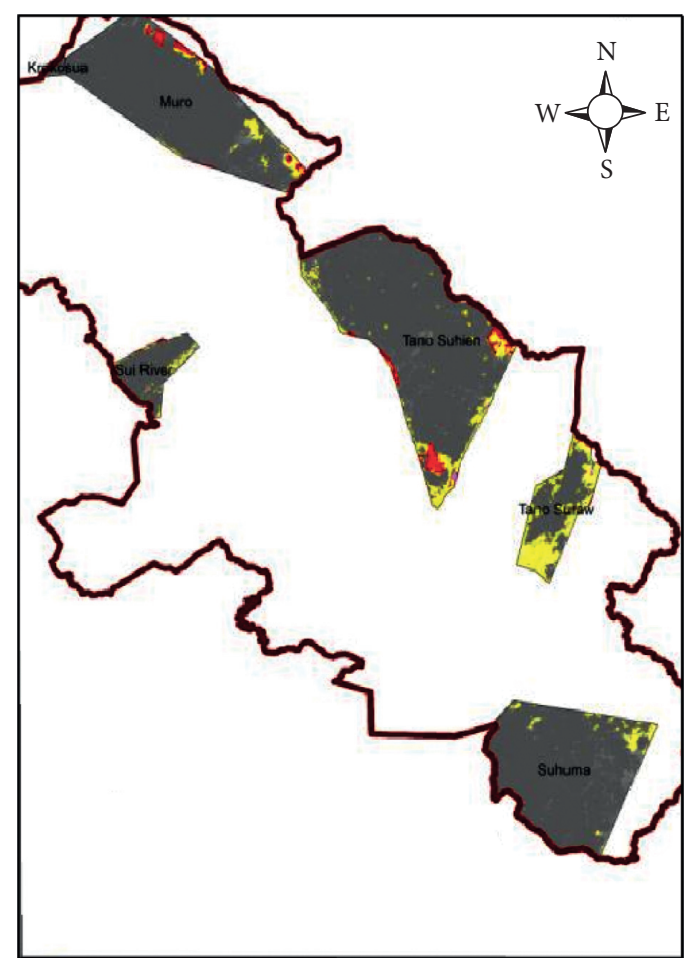

Close forest/open forest changing to farmlands

Unchanged close forest areas/areas changing to close forest Unchanged open forest areas/areas changing to open forest

(a)

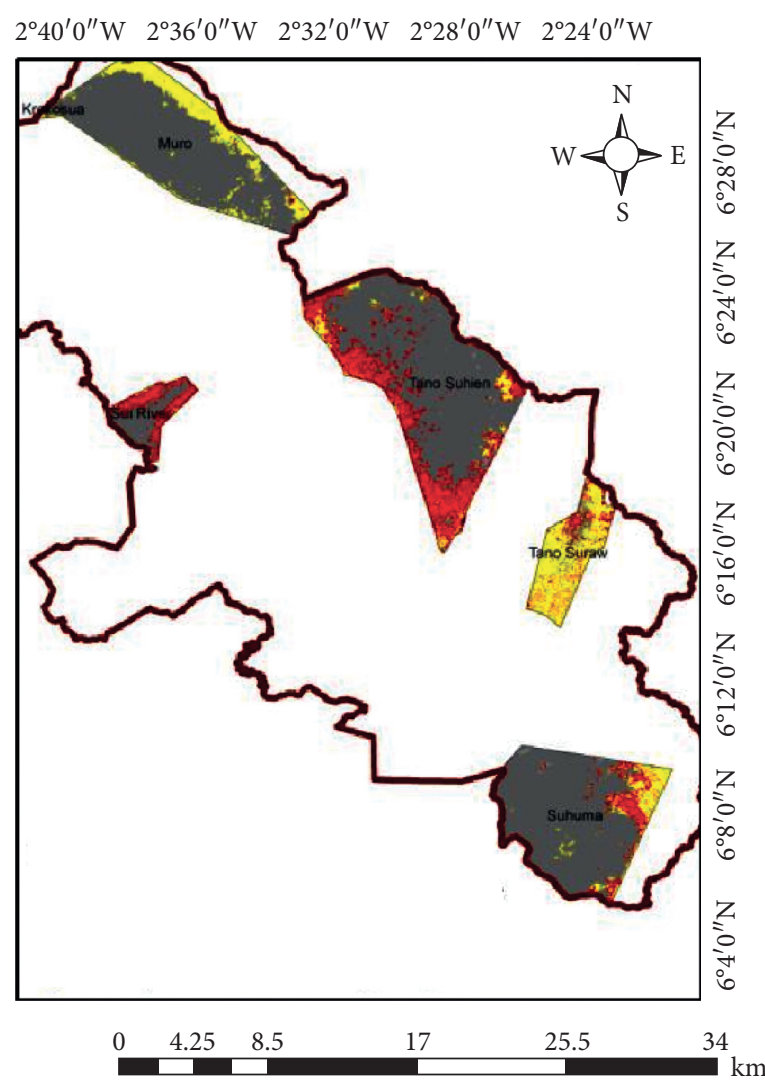

Coordinate system: WGS 1984 UTM zone 30N Projection: transverse mercator Datum: WGS 1984

Units: meter

FIgURE 11: Forest to farmland cover conversions from (a) 2000-2010 and (b) 2010-2017. 
TABle 10: Forest land cover areas in hectares (ha) lost and gained.

\begin{tabular}{lcc}
\hline & Cover change in hectares & $2010-2017$ \\
\hline Land cover & $2000-2010$ & -4622.94 \\
\hline (1) Closed FR & 110.25 & 1589.58 \\
(2) Open FR & -276.48 & 3036.96 \\
(3) Farmland & 284.94 & -11.34 \\
(4) Grassland & -104.58 & 7.29 \\
(5) Bareland & -14.13 & \\
\hline
\end{tabular}

TABLE 11: 2000-2010 forest to farmland conversion in hectares (ha).

\begin{tabular}{|c|c|c|c|c|c|c|}
\hline \multicolumn{7}{|c|}{2010} \\
\hline Land cover & Close forest & Open forest & Farmland & Grassland & Bareland & \\
\hline \multirow{5}{*}{2000} & Closed forest & 20810.5 & 1006.92 & 240.84 & 1.89 & 0 \\
\hline & Open forest & 1313.28 & 924.21 & 141.39 & 2.25 & 0 \\
\hline & Farmland & 22.86 & 95.58 & 23.22 & 2.61 & 0 \\
\hline & Grassland & 23.76 & 77.94 & 23.67 & 0.63 & 0 \\
\hline & Bareland & 0 & 0 & 0.09 & 14.04 & 0.09 \\
\hline
\end{tabular}

was converted to open forest cover from 2010 to 2017 (Table 12). A total of 3205.26 hectares (ha) of forest cover was converted to farmland cover from 2010 to 2017, which accounted for 2823.03 hectares (ha) increase compared to the previous 10 years. Farmland cover areas of 175.59 hectares (ha) within the six FRs were converted to open forest cover from 2010 to 2017. A total of 4622.94 hectares (ha) of close forest cover were removed from 2010 to 2017 within the FRs in the SWD.

3.3. Impact of Community Density. Community density was represented by spatially clustered points based on distance relationships between communities. Out of 24,802.53 hectares (ha) of FR areas inspected, 16,659 hectares (ha) were seen to be within the accessible zones of clustered fringe communities within the SWD. Tano Suhien, Tano Suraw, and Sui River FRs were inside the range of immediate community coverage (Figure 6 and Table 13). Based on closeness to highly dense community locations, eight risk classes of disturbance were created and tabulated to visualize threat to forest cover removal posed by fringe communities. It was revealed that 815 hectares (ha) of forest cover was found to be between high and critical disturbance risks (Table 14), since they were in direct contact with fringe community dwellers. Also, 4622.94 hectares (ha) of close forest cover within the high disturbance levels were removed from 2010 to 2017 with an increase of 3036 hectares (ha) in farmland cover in the same period.

3.4. Prediction Results. The simple moving averages forecasting method revealed that from 2017 to 2020, 144.31 hectares (ha) of close forest cover will be removed together with 125.44 hectares (ha) of open forest cover (Table 15). However, there will be an increase of 540.63 hectares (ha) in open forest cover from 2020 to 2024. Farmland cover will increase by 71.10 hectares (ha) from 2017 to 2020 and increase by 140.13 hectares (ha) from 2020 to 2024 .

\section{Discussion}

The pseudo images from LULC classification were validated using the error matrices. The subsamples for training and testing were systematic and was influenced by the report of [38] on the fitness of different ground truth sampling plans in satellite image accuracy assessment. The adapted assessment technique, however, allows room for improvement as the overall accuracy is biased since the number of sampling points per class is not the same.

The close forest cover areas in the images were reduced by 3210.022 hectares (ha) in four of the six FRs within the road buffers created. Farmland cover was not dominant in the year 2000 but had increased drastically by the year 2017 . This indicates that FRs nearest to accessible roads are targeted for illegal entry and economic activity. FRs whose boundaries are outside the $3 \mathrm{~km}$ road buffer zone show the lowest forest cover conversions. The road buffer intervals adopted here triggers early forest loss detection in protected forest areas relating to the study conducted by [33] in Amazon, which identified that unofficial roads within 5.5 kilometers of forest areas have bearings on deforestation rates. From the findings in this study, accessible roads near FRs were observed to provide gateways into FRs for illegal and destructive activities by forest fringe community dwellers.

Observations from findings also reveal small instances of farmland cover in the year 2000. Subsequently, farmland cover in the six FRs increased steadily from 2000 to 2010 but sharply from 2010 to 2017 . Priority was therefore given to large scale agriculture over forest conservation, since it is the primary source of livelihood amongst the forest fringe communities. The farmland cover conversions revealed by this research highlight a missing stance in early research 
TABLE 12: 2010-2017 forest to farmland conversion in hectares (ha).

\begin{tabular}{lccccc}
\hline \multirow{2}{*}{ Land cover } & & \multicolumn{2}{c}{2017} & & \\
& Close forest & Open forest & Farmland & Grassland & Bareland \\
\hline \multirow{3}{*}{2010} & Closed forest & 17301 & 2321.46 & 2522.61 & 8.46 \\
& Open forest & 229.5 & 1181.97 & 682.65 & 1.53 \\
& Farmland & 8.91 & 175.59 & 241.74 & 0.9 \\
& Grassland & 1.08 & 3.51 & 12.24 & 0 \\
\hline
\end{tabular}

TABLE 13: Forest cover trends in hectares (ha) for FRs dangerously within community access.

\begin{tabular}{lcccc}
\hline Forest reserve & Land cover & 2000 & 2010 & 2017 \\
\hline & Close FR & 1465.02 & 1089.18 & 167.58 \\
& Open FR & 459.9 & 847.17 & 1479.6 \\
Tano Suraw & Farmland & 9.18 & 5.04 & 292.68 \\
& Grassland & 11.07 & 3.78 & 5.31 \\
& Bareland & 0.09 & 0.09 & 0.54 \\
\hline \multirow{5}{*}{ Sui River } & Close FR & 1014.66 & 1042.2 & 645.57 \\
& Open FR & 142.11 & 108.18 & 22.5 \\
& Farmland & 3.69 & 14.58 & 495.72 \\
& Grassland & 4.5 & 0 & 0 \\
& Bareland & 0 & 0 & 0 \\
\hline \multirow{5}{*}{ Tano Suhien } & Close FR & 8163.27 & 8181.36 & 6479.91 \\
& Open FR & 748.08 & 672.93 & 442.62 \\
& Farmland & 116.46 & 256.77 & 2201.94 \\
& Grassland & 86.76 & 17.64 & 0 \\
& Bareland & 14.13 & 0 & 4.59 \\
\hline
\end{tabular}

TABLE 14: FR risk indication.

\begin{tabular}{lccc}
\hline Disturbance level & Area (ha) & Disturbance rank & Forest reserve \\
\hline None & 10479.96 & 1 & Sui River \\
Very low & 2681.55 & 2 & Tano Suraw \\
Low & 1260.54 & 3 & Tano Suhien \\
Moderate & 1415.97 & 4 & Muro \\
High & 369.63 & 5 & Suhuma \\
Very high & 306.45 & 6 & Krokosua \\
Severe & 100.8 & - & - \\
Critical & 38.43 & - & - \\
\hline
\end{tabular}

TABLE 15: 2020 and 2024 predicted forest cover areas in hectares (ha) in the SWD.

\begin{tabular}{lccccc}
\hline Land cover & 2000 & 2010 & 2017 & 2020 & 2024 \\
\hline Close forest & 22060.17 & 22165.86 & 17539.32 & 17397.825 & 16661.94 \\
Open forest & 2381.13 & 2100.09 & 3686.07 & 3561.57 & 4103.01 \\
Farmland & 144.27 & 424.65 & 3458.01 & 3529.655 & 3669.04 \\
Grassland & 70.25 & 3.52 & 6.67 & 141.27 & 165.23 \\
Bareland & 43.9 & 5.6 & 9.65 & 69.4 & 100.5 \\
\hline
\end{tabular}

studies like [39] which gives a general view that human activities such as agricultural expansion and illegal and unsustainable logging are responsible for the degradation of $85 \%$ of Ghana forest areas. Farmers tend to replace forest biodiversity with agricultural lands, which are considered more financially beneficial within the short term. Cash crops such as cocoa, cashew, and rubber are as a result more important to farming communities than biodiversity conservation.

The three most disturbed FRs based on community influence suffered a drastic reduction in the close forest area and an increase in the farmland area. In situ data collection and interviews revealed that forest fringe settlers engage in high-intensity small scale mining, large scale farming, chain saw operations, and illegal hunting within the nearby reserves [40]. FRs close to densely populated community locations showed rapid conversions from forest to nonforest cover.

Close forest areas will reduce steadily, while open forest areas will increase sharply from 2020 to 2024 after a steady reduction from 2017 to 2020 . The simple forecasting method looks smooth especially over the selected period. Barring any forest replacement interventions, farmlands will continue to increase.

\section{Conclusions and Recommendations}

Destructive human interference is promoted by accessibility through close accessible roads. Easy access routes enable proximate dwellers to easily access FRs undetected to illegally remove biodiversity. This research was unable to take into account the considerable number of unofficial routes through which proximate dwellers can access protected forest areas.

Conversion from forest to farmland cover is at a very high rate. Agricultural expansion rates continue to increase within FRs. The IUCN's categorization of FRs is undermined by the intrusion of extensive farming areas. The severe damage in FRs as a result of uncontrolled daily agricultural expansion could be monitored in further studies.

Population and community growth increase the intrusive risks in protected areas. Illegal human activities such as mining, farming, logging, and reckless fuelwood collection are practiced by fringe communities as a means of sustenance.

Year 2020 and 2024 predicted imagery showed trends of forest removal and farmland increase in the future. If conservation interventions do not improve, the adverse community impacts on FRs will be irreversible and unsustainable.

The stakeholders of the forest should consider real-time monitoring procedures, which account for subtle modes such as navigable rivers and skid trails areas which allow easy access to FRs. The emergence of illegal farms within protected forest areas should be discouraged. Laws concerning illegal entry into protected areas must be better enforced. 
The focus should increase on community-based participation in forest protection. Short interval imagery should be considered in the analysis of this nature to better depict unwanted conversions at an early stage. This will help identify impacts of dominant nonforest land cover, which is responsible for the conversion, and also measures the rate at which conversion has taken place with confidence.

\section{Data Availability}

The data used to support this study are included within this article.

\section{Conflicts of Interest}

The authors declare that there are no conflicts of interest regarding the publication of this paper.

\section{Acknowledgments}

The authors would like to acknowledge the Forestry Commission of Ghana and the Resource Management Support Center for their willingness to assist with this research where necessary. The authors also acknowledge all on-field participants in the SWD including farmers and fringe community dwellers who gave them the time and assistance when they needed it.

\section{References}

[1] G. Kissinger, M. Herold, and V. De Sy, "Drivers of deforestation and forest degradation," A Synthesis Report for REDD+ Policymakers, vol. 5, p. 48, 2012.

[2] V. De Cauwer, C. J. Geldenhuys, R. Aerts, M. Kabajani, and B. Muys, "Patterns of forest composition and their long term environmental drivers in the tropical dry forest transition zone of southern Africa," Forest Ecosystems, vol. 3, no. 1, 2016.

[3] A. Agrawal, D. Nepstad, and A. Chhatre, Reducing Emissions from Deforestation and Forest Degradation, Social Science Research Network, Rochester, NY, USA, 2011.

[4] R. Sousa-Silva, Q. Ponette, K. Verheyen, A. Van Herzele, and B. Muys, "Adaptation of forest management to climate change as perceived by forest owners and managers in Belgium," Forest Ecosystems, vol. 3, no. 1, 2016.

[5] R. Kong, J.-C. Diepart, J.-C. Castella et al., "Understanding the drivers of deforestation and agricultural transformations in the Northwestern uplands of Cambodia," Applied Geography, vol. 102, pp. 84-98, 2019.

[6] D. Armenteras, J. M. Espelta, N. Rodríguez, and J. Retana, "Deforestation dynamics and drivers in different forest types in Latin America: three decades of studies (1980-2010)," Global Environmental Change, vol. 46, pp. 139-147, 2017.

[7] J. Martins, D. M. Richardson, R. Henriques et al., "A multiscale modelling framework to guide management of plant invasions in a transboundary context," Forest Ecosystems, vol. 3, no. 1, 2016.

[8] Å. S. Jørgensrud, Farm Household Vulnerability and Adaptive Capacity to the Double Exposure of Climate Change and Structural Change A Case Study of a Farming Community in Western Norway, Norwegian University of Life Sciences, Ås, Norway, 2014.
[9] M. Bare, C. Kauffman, and D. C. Miller, "Assessing the impact of international conservation aid on deforestation in subSaharan Africa," Environmental Research Letters, vol. 10, no. 12, Article ID 125010, 2015.

[10] T. Yoshikura, M. Amano, H. Chikaraishi, B. Supriyanto, and D. Wardhana, "Evaluation of appropriate identification of deforestation agents and drivers for designing REDD+ readiness activities through an examination of the area around Gunung Palung national park, Indonesia," Open Journal of Forestry, vol. 06, no. 02, pp. 106-122, 2016.

[11] N. Hosonuma, M. Herold, V. De Sy et al., "An assessment of deforestation and forest degradation drivers in developing countries," Environmental Research Letters, vol. 7, no. 4, Article ID 044009, 2012.

[12] J. E. Makunga and S. B. Misana, "The extent and drivers of deforestation and forest degradation in Masito-Ugalla ecosystem, Kigoma region, Tanzania," Open Journal of Forestry, vol. 7, no. 2, pp. 285-305, 2017.

[13] Ministry of Lands and Natural Resources, National Forest Plantation Development Programme 2016 Annual Report Forest Services Division-Forestry Commission, Ministry of Lands and Natural Resources, Accra, Ghana, 2016.

[14] S. Labant, M. Bindzarova Gergelova, Z. Kuzevicova, S. Kuzevic, G. Fedorko, and V. Molnar, "Utilization of geodetic methods results in small open-pit mine conditions: a case study from Slovakia," Minerals, vol. 10, no. 6, pp. 489-521, 2020.

[15] A. Awotwi, G. K. Anornu, J. Quaye-Ballard, T. Annor, and E. K. Forkuo, "Analysis of climate and anthropogenic impacts on runoff in the lower Pra river basin of Ghana," Heliyon, vol. 3, no. 12, Article ID e00477, 2017.

[16] L. F. Temgoua, B. Allaissem, M. Tchamba, G. Saradoum, M. M. Osée, and M. C. M. Solefack, "Spatio-temporal dynamic of land use and land cover in the classified forest of Djoli-Kera, south-eastern, Chad," Open Journal of Forestry, vol. 8, no. 3, pp. 283-296, 2018.

[17] S. Puliti, H. Ørka, T. Gobakken, and E. Næsset, "Inventory of small forest areas using an unmanned aerial system," Remote Sensing, vol. 7, no. 8, pp. 9632-9654, 2015.

[18] T. V. Ramachandra, B. Setturu, and S. Chandran, "Geospatial analysis of forest fragmentation in Uttara Kannada district, India," Forest Ecosystem, vol. 3, no. 1, 2016.

[19] Y. Farhan, D. Zreqat, A. Anbar, H. Almohammad, and S. Alshawamreh, "Prioritization of W. Mujib catchment (South Jordan) through morphometric and discriminant analysis, GIS, and RS techniques," Journal of Geoscience and Environment Protection, vol. 6, no. 4, pp. 141-171, 2018.

[20] M. Roque, J. Ferreira Neto, A. Faria, F. Ferreira, T. Teixeira, and L. Coelho, "Effectiveness of arguments used in the creation of protected areas of sustainable use in Brazil: a case study from the Atlantic forest and Cerrado," Sustainability, vol. 11 , no. 6 , p. $1700,2019$.

[21] N. Senturk, "Assessment of relationship between locations and distances to roadside of forest fires in Istanbul, Turkey," Applied Ecology and Environmental Research, vol. 16, no. 5, pp. 6195-6204, 2018.

[22] S. Estel, T. Kuemmerle, C. Alcántara, C. Levers, A. Prishchepov, and P. Hostert, "Mapping farmland abandonment and recultivation across Europe using MODIS NDVI time series," Remote Sensing of Environment, vol. 163, pp. 312-325, 2015.

[23] V. A. Soifer, "Computer processing of images," Vestn Ross Akad Med Nauk, vol. 71, no. 2, pp. 119-129, 2001. 
[24] E. H. Owusu, B. Y. Ofori, and D. K. Attuquayefio, "The secondary impact of mining on primates and other medium to large mammals in forest reserves in southwestern Ghana," The Extractive Industries and Society, vol. 5, no. 1, pp. 114-121, 2018.

[25] E. Lartey, "Forest fringe communities' perspective on the socio-economic and land use impacts of granting timber rights: case study of Ghana," International Journal of Social Forestry, vol. 2, no. 2, pp. 167-184, 2009.

[26] Food and Agriculture Organization, The State of the World's Forest Genetic Resources Ghana Country Report, Food and Agriculture Organization, 2010, http://www.fao.org/3/i3825e/ i3825e29.pdf.

[27] Ö. M. Soysal and C. D. Guempel, et al., Zonal Statistics to Identify Hot-Regions of Traffic Accidents, vol. 3, Louisiana State University, Baton Rouge, LA, USA, 2012, https://www. semanticscholar.org/author/P.-Li/145915574.

[28] T. Kuemmerle, O. Chaskovskyy, J. Knorn et al., "Forest cover change and illegal logging in the Ukrainian Carpathians in the transition period from 1988 to 2007," Remote Sensing of Environment, vol. 113, no. 6, pp. 1194-1207, 2009.

[29] E. D. Wiafe, K. B. Dakwa, and S. Yeboah, "Assemblages of avian communities in forest elephant (Loxodonta cyclotis) range in Ghana," Pachyderm, vol. 48, no. 1, pp. 41-47, 2010.

[30] A. Doxa, M. L. Paracchini, P. Pointereau, V. Devictor, and F. Jiguet, "Preventing biotic homogenization of farmland bird communities: the role of high nature value farmland," Agriculture, Ecosystems \& Environment, vol. 148, pp. 83-88, 2012.

[31] G. M. Foody, "Status of land cover classification accuracy assessment," Remote Sensing of Environment, vol. 80, no. 1, pp. 185-201, 2002.

[32] S. S. Rwanga and J. M. Ndambuki, "Accuracy assessment of land use/land cover classification using remote sensing and GIS," International Journal of Geosciences, vol. 8, no. 4, pp. 611-622, 2017.

[33] C. P. Barber, M. A. Cochrane, C. M. Souza, and W. F. Laurance, "Roads, deforestation, and the mitigating effect of protected areas in the Amazon," Biological Conservation, vol. 177, pp. 203-209, 2014.

[34] T. Davies and S. D. Johnson, "Examining the relationship between road structure and burglary risk via quantitative network analysis," Journal of Quantitative Criminology, vol. 31, no. 3, pp. 481-507, 2015.

[35] W. J. Fu, P. K. Jiang, G. M. Zhou, and K. L. Zhao, "Using Moran's I and GIS to study the spatial pattern of forest litter carbon density in a subtropical region of southeastern China," Biogeosciences, vol. 11, no. 8, pp. 2401-2409, 2014.

[36] W. L. Winston and J. B. Goldberg, Operations Research: Applications and Algorithms, Vol. 3, Calif: Thomson, Brooks, Cole, Belmont, vol. 3, Calif: Thomson, Brooks, Cole, Belmont, CA, USA, 2004.

[37] A. M. Alhassan, Analysis of Primary Stakeholders Participation in Forest Resources Management: The Case of the Krokosua Hills Forest Reserve, Kwame Nkrumah University of Science and Technology, Kumasi, Ghana, 2010.

[38] G. Ruppert, M. Hussain, and H. Müller, “Accuracy assessment of satellite image classification depending on training sample," Austrian Journal of Statistics, vol. 28, no. 4, 1999.

[39] E. O. Acheampong, C. J. Macgregor, S. Sloan, and J. Sayer, "Deforestation is driven by agricultural expansion in Ghana's forest reserves," Scientific African, vol. 5, Article ID e00146, 2019.

[40] M. K. McCall and P. A. Minang, "Assessing participatory GIS for community-based natural resource management: claiming community forests in Cameroon," The Geographical Journal, vol. 171, no. 4, pp. 340-356, 2005. 